\title{
Notes
}

\section{Dunlop v. Bachowski and the Limits of Judicial Review under Title IV of the LMRDA: A Proposal for Administrative Reform*}

In 1959 Congress passed the Labor-Management Reporting and Disclosure Act (LMRDA). ${ }^{1}$ The goals of the Act were to guarantee the political and civil rights of union members within their unions and to make union officers more responsive to members' welfare. ${ }^{2}$ Title IV of the Act established standards to ensure free and democratic union elections ${ }^{3}$ and empowered the Secretary of Labor to bring suit to overturn elections upon a member's complaint that those standards were breached. ${ }^{*}$ Congress made the Secretary's suit the

- The author is grateful to the Labor Department for its generous cooperation and assistance.

1. Labor-Management Reporting and Disclosure (Landrum-Griffin) Act of 1959, 29 U.S.C. $\$ \$ 401-531$ (1970). The legislative history of the Act is gathered in U.S. Solicitor of the Dep't of Labor, Legislative History of the Labor-Management Reporting aND Disclosure Act of 1959: Tirtes I-VI (1964) [hereinafter cited as Legislative History]. For discussion of the political background of the Act, see A. MCADAMs, POWER AND Polmtics in LABOR LegisLATION (1964).

2. LMRDA $\S 2,29$ U.S.C. $\S 401$ (1970). The Act was, in part, Congress's response to the corrupt union practices uncovered by the Senate Select Committee on Improper Activities in the Labor or Management Field. See A. McAdams, supra note 1, at 273 (crucial factor in passage of LMRDA was public reaction to labor corruption uncovered by Select Committee); Cox, Internal Affairs of Labor Unions under the Labor-Management Reporting and Disclosure Act of 1959, 58 МicH. L. Rev. 819 (1960).

3. LMRDA $\S 401,29$ U.S.C. $\$ 481$ (1970). Section 401 requires that elections be held at least once every three years for local union officers, at least once every four years for officers of intermediate union bodies, and at least once every five years for officers of national or international labor organizations. Election of all officers is by secret ballot among members in good standing or (in non-local elections) by vote of a convention of delegates chosen by secret ballot. $I d$. $\$ 481$ (a), (b), (d). Section 401(c) prohibits discriminatory use of membership lists and union distribution of campaign literature; it also provides safeguards to ensure fair elections, including the right of any candidate to have observers at the polls and at the ballot count. $I d . \S 481$ (c).

Any member in good standing is eligible to be a candidate and hold office (subject to reasonable qualifications uniformly imposed); each member in good standing must receive notice of an election and is entitled to one vote. $I d . \$ 481(\mathrm{e})$. Elections and conventions must be conducted in accordance with the constitution and bylaws of the union, insofar as those provisions are not inconsistent with the LMRDA. Id. \& 481(e), (f). Union funds may not be used to promote the candidacy of any person in an election subject to Title IV. Id. $\$ 481(\mathrm{~g})$. If the Secretary of Labor determines that union procedures for removal of officers are inadequate, he may conduct new elections. Id. $\$ 481(\mathrm{~h})$, (i). See generally 29 C.F.R. $\$ \$ 452.1-.134$ (1976) (Labor Department rules interpreting $\$ 401)$.

4. LMRDA $\S 402,29$ U.S.C. $\S 482$ (1970), outlines the procedure for enforcement when violations have occurred. After a member has exhausted his internal union 
exclusive post-election remedy for election violations; union members cannot bring private actions. ${ }^{5}$

During the 1960s the Supreme Court recognized the Secretary's broad authority to investigate complaints and bring suits in order to guarantee union democracy. ${ }^{6}$ However, the individual interest of the complaining union member was ignored by the courts ${ }^{7}$ until the

remedies (or has invoked those remedies without obtaining a final decision within three months), he may, within one month, file a complaint with the Secretary of Labor alleging violation of $\$ 401$. Id. $\$ 482(a)$. The Secretary shall investigate the complaint. If he finds probable cause to believe that a violation of LMRDA $\$ 401,29$ U.S.C. $\$ 481$ (1970), has occurred and has not been remedied, he shall bring suit against the union within 60 days after receiving the initial complaint. Id. $\$ 482(\mathrm{~b})$. If the court finds that an election has not been held with the frequency required by $\$ 401$ or that violations of $\$ 401$ may have affected the outcome of the election, it shall void the election and order the holding of a new election supervised by the Secretary. The Secretary shall certify to the court the names of the persons elected in the rerun election, and the court then shall enter a decree declaring those persons to be the officers of the labor organization. Id. $\$ 482$ (c).

5. LMRDA $\$ 403,29$ U.S.C. $\$ 483$ (1970).

6. In Calhoon v. Harvey, 379 U.S. 134, 140 (1964), the Supreme Court held that a union member cannot challenge allegedly discriminatory nomination rules in a suit under 29 U.S.C. $\$ 411(a)(1)(1970)$, and that his sole remedy lies in a suit by the Secretary under $i d$. $\$ 482(b)$. The Court explained that Congress vested the Secretary with exclusive power to bring suit in order

to utilize the special knowledge and discretion of the Secretary of Labor in order best to serve the public interest. . . . Reliance on the discretion of the Secretary is in harmony with the general congressional policy to allow unions great latitude in resolving their own internal controversics, and, where that fails, to utilize the agencies of Government most familiar with union problems to aid in bringing about a settlement through discussion before resort to the courts.

379 U.S. at 140. See Wirtz v. Local 153, Glass Bottle Blowers Ass'n, 389 U.S. 463, 473 n.11 (1968) (Congress intended to confer "broad power" on Secretary); Wirtz v. Local 125, Laborers Int'1 Union, 389 U.S. 477, $482-83$ (1968) (Secretary's complaint not strictly limited to member's original allegations because such limitation "would be inconsistent with [the Secretary's] vital role . . . in protecting the public interest bound up in Title IV" and because "[t]he expertise and resources of the Labor Department were surely meant to have a broader play").

7. Despite the Supreme Court's confidence in the Department of Labor's enforcement of Title IV, union dissidents from 1964 to 1971 claimed that the Secretary was unresponsive to complainants and generally lax in filing and prosecuting Title IV suits. See, e.g., Hall, Introduction, in AuTOCRACY ANd INSURGeNcy IN ORGanized LABoR 1, 5-8 (B. Hall ed. 1972) [hereinafter cited as AuTocRAcy] (discussing the need for democratic reform of union leadership and viewing Department of Labor as obstacle to efforts of union reformers).

As a result of their lack of confidence in the Secretary's handling of Title IV suits, complainants went into court, seeking to control or challenge the Secretary's conduct of such suits. However, courts refused to entertain the challenges, holding that the Secretary's exclusive right to bring Title IV suits precluded private parties from objecting to the Secretary's decisions. Complainants challenged the Secretary's decisions at each stage of Title IV litigation: (1) Decisions not to Bring Suit: McArthy v. Wirtz, 65 L.R.R.M. 2411 (E.D. Mo. 1967); Katrinic v. Wirtz, 62 L.R.R.M. 2557 (D.D.C. 1966); Altman v. Wirtz, 56 L.R.R.M. 2651 (D.D.C. 1964). Cf. Orphan v. Hodgson, 78 L.R.R.M. 2825 (N.D. Ill. 1971) (court has no jurisdiction to compel Secretary to investigate preelection violations). (2) Decisions to Accept Formal Consent Agreement with Defendant Union: Stein v. Wirtz, 366 F.2d 188 (10th Cir. 1966), cert. denied, 386 U.S. 996 (1967) (denial of complainant intervention challenging stipulation between union and Secre- 
Supreme Court's decision in Trbovich $v . U M W .^{8}$ There the Court held that the Title IV complainant has a right to intervene in the Secretary's suit. ${ }^{9}$ Trbovich prompted greater judicial recognition of the complainant's rights. ${ }^{10}$ Most recently, the Supreme Court held in

tary); Shultz v. Steelworkers Dist. 15, 312 F. Supp. 1044 (W.D. Pa. 1970) (similar). (3) Decisions concerning the Formulation and Enforcement of Rules for Supervised Election: Wirtz v. NMU, 409 F.2d 1340 (2d Cir. 1969) (union member has no standing to challenge' Secretary's rules). (4) Decisions to Certify Results of Supervised Election: Morrissey v. Shultz, 311 F. Supp. 744 (S.D.N.Y. 1970) (court cannot entertain suit against Secretary to compel new rerun election); Wirtz v. Local 1377, IBEW, 288 F. Supp. 914 (N.D. Ohio 1968) (union member cannot intervene in Title IV suit to allege irregularities in supervised election). In only two reported cases before 1972, both involving review of the Secretary's decision not to bring suit, did courts allow private parties to come into court to object to the Secretary's actions. But neither suit ultimately rendered the relief sought by the complainants. See DeVito v. Shultz, 72 L.R.R.M. 2682 (D.D.C. 1969); Schonfeld v. Wirtz, 258 F. Supp. 705 (S.D.N.Y. 1966).

8. 404 U.S. 528 (1972). The plaintiff was a union dissident seeking to intervene in a Title IV suit against the Mine Workers, so that he could add allegations to the Secretary's complaint, suggest specific rules to be enforced in the rerun election that would be ordered if the Secretary won the suit, and present evidence and argumentation in support of the Secretary's challenge to the 1969 election. Id. at 529-30. Underlying this motion for intervention was deep dissatisfaction with the Secretary's enforcement of Title IV, shared by Mine Worker reformers and their attorneys. See United Mine Workers' Election 1971: Hearings Before the Subcomm. on Labor of the Senate Comm. on Labor and Public Welfare (Part II), 92d Cong., Ist Sess. 5-6, 16, 24-25, 27-28, 30-32, 34-35, 60-61, 63 (1971) [hereinafter cited as UMW Hearings II]; Feldman, Miners for Democracy, in AutocracY, supra note 7, at 11, 13-14, 17-18; Rauh, LMRDA-Enforce It or Repeal It, 5 GA. L. REV. 643, 651-58 (1971). See also Kalis, Private Litigation and the UMW, 3 YALE REv. L. \& Soc. Action 272 (1973) (describing other UMW dissident suits).

9. The Court acknowledged that Title IV was intended to protect unions from decentralized and frivolous litigation. The Court reasoned that intervention designed only to assist the Secretary in proving his case and in formulating rules for the supervised election would impose no additional burden on the union. Trbovich v. UMW, 404 U.S. $528,536-37(1972)$.

10. From 1972 to 1975 , courts upheld the legal right of complainants to challenge the Secretary's decisions at various stages of Title IV litigation:

(1) Decisions to Accept Formal Consent Agreement with Defendant Union: Brennan v. District 50, Allied \& Technical Workers, 499 F.2d 1051 (D.C. Cir. 1974) (upholding consent agreement); Brennan v. Steelworkers Dist. 15, Civ. No. 73-957A (W.D. Pa. Dec. 12, 1974) (same); Brennan v. Steelworkers Dist. 31, Civ. No. 73-957B (W.D. Pa. Dec. 2, 1974) (same, Aug. 23, 1974); Brennan v. Connecticut State UAW Community Action Program Council, 373 F. Supp. 286 (D. Conn. 1974) (modifying consent agreement); Hodgson v. Local 44, Upholsterers, Civ. No. 72-4600 (S.D.N.Y. Oct. 31, 1974) (upholding consent agreement, Feb. 6, 1974); Casey v. Brennan, No. C-73-0836 AVZ (N.D. Cal. Oct. 19. 1973) (unsuccessful mandamus action to compel Secretary to reject pre-complaint consent agreement and bring suit).

(2) Decisions Concerning the Formulation and Enforcement of Rules for Supervised Election: Bibbs v. Brennan, Civ. No. 74-1562 EC (C.D. Cal. Aug. 1, 1974) (intervenor's successful challenge to exclusion from ballot in supervised election); Rollins v. UMW (Brennan), Civ. No. 1753-73 (D.D.C. Sept. 18, 1973) (unsuccessful mandamus action); Hodgson v. UMW, 81 L.R.R.M. 2840 (D.D.C. 1972) (challenge to Secretary's rules). See also Brennan v. UMW, 82 L.R.R.M. 2699 (D.D.C. 1973) (interpreting Hodgson v. UMW, 81 L.R.R.M. 2505 (D.D.C. 1972) (intervenor in Title III suit successfully challenging Sccretary's interpretation of rules for supervised election)).

(3) Decisions to Cerlify Resulls of Supervised Election: Hodgson v. Carpenters Resilient Flooring Local 2212, 457 F.2d 1364 (3d Cir. 1972) (intervention by defeated officer to 
Dunlop v. Bachowski1 that the Secretary's decision not to sue is subject to judicial review at the instance of the complainant. ${ }^{12}$

This Note argues that judicial review under Bachowski has been unsatisfactory as a means of protecting individual rights and that the ultimate solution lies with the Department of Labor or Congress. ${ }^{13}$ The review process contravenes the statutory goals of Title IV's enforcement scheme and provides inadequate protection for the complainant's interest in the suit. Indeed, the problem underlying the Bachowski litigation is that the Labor Department's investigatory process does not have rules and procedures necessary to ensure openness, apparent fairness, and sufficient consideration of the complainant's point of view. The Note proposes that Congress overrule Bachowski by amending Title IV to preclude judicial review and that judicial review be replaced by administrative procedures within the Labor Department. The recommended procedures, providing for informal hearing and review analogous to that used in NLRB cases, would give complainants a more meaningful voice without impairing the special enforcement goals of Title IV.

challenge Secretary's certification); Hodgson v. Local 44, Upholsterers, Civ. No. 72.4600 (S.D.N.Y. Oct. 31, 1975) (intervenors' unsuccessful challenge to Secretary's certification of election); Brennan v. Local 639, Teamsters, Civ. No. $1963-72$ (D.D.C. June 24, 1974), rev'd on other grounds sub nom. Usery v. Local 639, Teamsters, 543 F.2d 369 (D.C. Cir. 1976) (same). But see Usery v. District 22, UMIW, 93 L.R.R.M. 2364 (D. Utah 1976) (intervention to challenge certification denied under Bachowski standard of review).

11. 421 U.S. 560 (1975). The plaintiff had narrowly lost a 1973 election in Steclworkers District 20 and filed a timely complaint with the Secretary. The Secretary investigated the allegations and found that "civil action to set aside the challenged election [was] not warranted." Id. at 563. The complainant brought suit in the Western District of Pennsylvania, requesting the court to "declare the actions of the Defendant Secretary to be arbitrary and capricious and order him to file suit to set aside the . . election." Id. at 564. For a discussion of the legal and factual background of the Bachowshi case, see Comment, Judicial Review of Administrative Discretion under Title IV of the LaborManagement Reporting and Disclosure Act of 1959 After Dunlop v. Bachowski, 10 GA. L. REv. 818 (1976).

12. Several lower courts had already reached this conclusion. See Bachowski v. Brennan, 502 F.2d 79 (3d Cir. 1974), rev'd on other grounds sub nom. Dunlop v. Bachowski, 421 U.S. 560 (1975) (Secretary's decision not to sue subject to judicial review, including factual inquiry into bases of Secretary's decision); Valenta v. Brennan, 90 L.R.R.M. 3313 (N.D. Ohio 1974), appeal dismissed, No. 76-1122 (6th Cir. Feb. 24, 1977) (same); DeVito v. Shultz, 72 L.R.R.M. 2682 (D.D.C. 1969) (judicial review limited to cxamination of Secretary's statement of reasons); Schonfeld v. Wirtz, 258 F. Supp. 705 (S.D.N.Y. 1966) (Secretary's discretion reviewable by court). See also Hopson, Judicial Review of the Secretary of Labor's Decision Not to Sue to Set Aside a Union Election Under Title IV of the LMRDA, 18 WAYNE L. REv. 1281, 1302-05 (1972) (pre-Bachowshi endorsement of judicial review of Secretary's decisions not to sue).

13. Scholarly commentary has noted and criticized Bachowski for its narrow scope of review, but without carefully analyzing the case's impact on national labor policy. See Schwartz, Administrative Law Cases During 1975, 28 AD. L. REv. 131, 143-44 (1976); 17 B.C. INdus. \& Com. L. Rev. 581 (1976); Address by Florian Bartosic, Convention of the ABA's Labor Law Section (1975), reprinted in [1975] Labor ReLATIONS YEarbook (BNA) $61,69-70$. 


\section{Problems with Judicial Review under Bachowski}

In vesting the Secretary with exclusive power to bring Title IV suits, Congress's general goal was to provide an effective remedy for violations of Title IV's election requirements, but with minimum governmental interference in the affairs of labor unions. ${ }^{14}$ Behind this general goal of minimizing governmental interference are two specific goals: to prevent frivolous and decentralized litigation against unions ${ }^{15}$ and to settle quickly the cloud on officers' title when unmeritorious challenges are made against the validity of elections. ${ }^{16}$ The role of the Secretary in Title IV litigation is primarily to protect the "public interest"-the preservation of union democracy without undue intrusion into union affairs. Yet Congress also intended the Secretary to be the "lawyer" enforcing the complainant's right to free and democratic elections in his union. ${ }^{17}$ The Bachowski Court implicitly recognized some conflict between the Secretary's broad power and discretion and his duty to protect the complainant's interests; the Court sought to reach a compromise between these competing concerns. ${ }^{18}$

Specifically, Bachowski presented two questions: whether the Secretary's decision not to bring a Title IV suit is subject to judicial

14. See Wirtz v. Local 153, Glass Bottle Blowers Ass'n, 389 U.S. 463, 470-71 (1968); S. ReP. No. 1684, 85th Cong., 2d Sess. 4-5 (1958), reprinted in Lecislative History, supra note 1, at 24-25; S. REP. No. 187, 86th Cong., Ist Sess. 7 (1959), reprinted in LegisLative History, supra note 1, at 118; A. McAdams, supra note 1, at 98; Mitchell, Safeguards for Union Democracy, in SYMPosium on LMRDA 135, 135-41 (R. Slovenko ed. 1961).

15. The Conference Committee which drafted the final version of the LMRDA clearly intended the Secretary's suit to be the exclusive remedy for union election violations; the Committee rejected the House version, which authorized suits by union members. H.R. CoNf. Rer. No. 1147, 86th Cong., Ist Sess. 34-35 (1959), reprinted in LegisLATIVe History, supra note 1 , at 835 . This choice reflected Congress's fear that unions would be afflicted with harassing and diffuse litigation unless some agency could centralize litigation and screen out frivolous complaints. See Dunlop v. Bachowski, 421 U.S. 560, 569-70, 573 (1975); Trbovich v. UMIW, 404 U.S. 528, 532-36 (1972). See generally LaborManagement Reform Legislation: Hearings on S.505, S.7.7S, S.76, S.1002, S.1137, and S.1311 Before the Subcomm. on Labor of the Senate Comm. on Labor and Public Welfare, 86th Cong., lst Sess. 135, 567, 578-79 (1959) (testimony reflecting unions' fear of frivolous litigation).

16. Dunlop v. Bachowski, 421 U.S. 560, 569, 573 (1975); Wirtz v. Local 153, Glass Bottle Blowers Ass'n, 389 U.S. 463, $468 \mathrm{n} .7$ (1968). Congress intended that union election challenges, unless warranted by the Secretary, should be disposed of quickly, so that the union's officers would not be hampered in acting for the union and in bargaining with employers.

17. 104 CoNg. REc. 10947 (1958) (Sen. Kennedy, Senate sponsor of LMRDA). See Dunlop v. Bachowski, 421 U.S. 560, 572 (1975); Trbovich v. UMW, 404 U.S. 528, 538-39 (1972).

18. But see 17 B.C. Indus. \& CoMr. L. Rev. $581,595,598$ n.143 (1976) (under principles of administrative law, the Court's assumption that the Secretary's decision is not unreviewable under 5 U.S.C. $\$ 701$ (a)(2) (1970) as "committed to agency discretion" is in conflict with the Court's conclusion that the scope of review must be very narrow because of the special knowledge and discretion of the Secretary). 
review and, if so, what the proper scope of review should be. ${ }^{19}$ The Supreme Court held the Secretary's decision reviewable, but limited review to examination of the Secretary's statement of reasons for not bringing suit, without investigation into the accuracy of the facts on which his refusal was based. ${ }^{20}$ If the reviewing court finds the statement rational on its face, the Secretary's decision will be upheld. If the reviewing court finds the statement "so irrational as to constitute the decision arbitrary and capricious," 21 the decision will be remanded to the Secretary for a supplemental statement of reasons. The Supreme Court reserved the question whether a court can compel the Secretary to bring suit if supplemental statements remain unsatisfactory. ${ }^{22}$

Bachowski was an attempt to achieve a compromise between competing statutory goals, but in practice the compromise has failed to realize either goal. Judicial review has contravened two of Title IV's enforcement objectives: protection of unions from potentially frivolous suits and speedy resolution of post-election controversies. Yet the scope of review granted in Bachowski is so narrow that it affords scant protection for the complainant's rights.

\section{A. Impairment of the Enforcement Scheme}

Title IV vests exclusive enforcement of post-election remedies with the Secretary in order "to prevent members from pressing claims not thought meritorious by the Secretary and from litigating in forums or at times different from those chosen by the Secretary." ${ }^{23}$ By screening

19. Dunlop v. Bachowski, 421 U.S. 560, 564-65 (1975).

20. Id. at 572-73. The scope of review extends beyond the reasons statement only in the "rare case" where a plaintiff proves that the Secretary's decision is "plainly beyond the bounds of the Act [or] clearly defiant of the Act." Id. at 574 (quoting DeVito v. Shultz, 72 L.R.R.M. 2682, 2682 (D.D.C. 1969)). For example, “ 'if the Secretary prosecuted complaints in a constitutionally discriminatory manner," " a reviewing court might engage in a factual inquiry. $I d$. (quoting Brief for Petitioner at 9 n.3, Dunlop v. Bachowski, 421 U.S. $560(1975)$ ).

21. Dunlop v. Bachowski, 421 U.S. at 575; see id. at 574-75 \& $\mathrm{n.11}$ (approving DeVito v. Shultz, 72 L.R.R.M. 2682 (D.D.C. 1969)).

22. Id. at 575-76.

23. Trbovich v. UMW, 404 U.S. 528, 536 (1972). The Trbovich Court was careful to tailor the right of intervention narrowly to protect the congressional purpose. Furthermore, the Court limited the intervenor's role to the presentation of evidence in support of the Secretary and participation in the formulation of rules for the supervised election. Id. at 536-37. The Court held that the intervenor could add no new allegations to the Secretary's complaint:

[T]o require the union to respond to these claims would be to circumvent the screening function assigned by statute to the Secretary. We recognize that it is less burdensome for the union to respond to new claims in the context of the pending suit than it would be to respond to a new and independent complaint. Nevertieless, we think Congress intended to insulate the union from any complaint that did not appear meritorious to both a complaining member and the Secretary. Id. at $\mathbf{5 3 7}$. 
out frivolous complaints, the Secretary is meant to shield unions from the hazards and expense of unnecessary litigation-publicity, harassment, discovery, and attorneys' fees. ${ }^{24}$

Notwithstanding this express goal of Title IV, unions are frequently defendants in suits for judicial review of the Secretary's decisions not to bring suit. For instance, the Steelworkers union was a named defendant in Dunlop v. Bachowski. ${ }^{25}$ Before the Supreme Court, the Steelworkers argued that suits for judicial review necessarily involve the union and that such litigation therefore defeats the Secretary's screening function. ${ }^{26}$ The union's argument was unsuccessful; indeed, it was entirely ignored by the Court.

However, it is clear that the Steelworkers' argument has merit. The union has a strong interest in preventing the institution of a disruptive Title IV suit and therefore understandably supports the Secretary's decision not to sue. ${ }^{27}$ The interest is not simply the desire to

24. Congress is still committed to the policy of protecting unions from harassing litigation. See note 70 infra. Cf. D. BoK \& J. Dunlop, Labor aNd the AMerican ComMUNITY 90-91 (1970) (arguing that proper labor policy should not overemphasize "pure" elective democracy in unions to the disruption of the efficient functioning of the union as a bargaining organization). For example, complainants may attempt to use the judicial process to embarrass unions and their leadership. See, e.g., Intervenors' Memorandum in Opposition to Entry of Judgment at 7-9, Brennan v. Connecticut State UAW Community Action Program Council, 373 F. Supp. 286 (D. Conn. 1974) (Trbovich intervenor using power to take depositions to bring in issues of official malfeasance and to embarrass union and officials); Motion for Order Granting Leave to Intervene, Affidavit of John J. Balistreri (complainant seeking to intervene in Title IV suit to ask the court "to dissolve the Marine Cooks and Stewards Union as being an unlawful syndicate of organized crime") \& Declaration of Joseph C. Burton in Opposition to Motion for Permission to Intervene (noting that intervenor's attorney had brought nine frivolous suits against defendant union, alleging damages totaling $\$ 202,338,853)$, Brennan v. Marine Cooks \& Stewards Union, No. 73-1143 SC (N.D. Cal. Nov. 12, 1974).

25. Bachowski v. Brennan, 502 F.2d 79, 82 (3d Cir. 1974), rev'd sub nom. Dunlop v. Bachowski, 42L U.S. 560 (1975); Brief for the United Steelworkers of America at 7 , Dunlop v. Bachowski, 421 U.S. 560 (1975).

26. See Brief for Petitioners at 21, Dunlop v. Bachowski, 421 U.S. 560 (1975):

The union could be (as it was in this case) named as a defendant in the suit nominally against the Secretary; it could thus be "haled into court, virtually without limitation" [Labor-Management Reform Legislation: Hearings on S.505, S.748, S.76, S.1002, S.1137, and S.1311 Before the Subcomm. on Labor of the Senate Comm. on Labor and Public Welfare, 86th Cong., Ist Sess. 567 (1959) (statement of Andrew Biemiller, AFL.CIO)]. And, even if not named a defendant in the complaint, the union would need to defend the suit as an intervenor or amicus since it, as well as the Secretary, is a real party in interest; if the Secretary is ordered to commence a Title IV suit, the union must defend its election.

Respondent answered this argument unconvincingly: "At any rate, the primary burden of defending the litigation would be on the Secretary of Labor." Bricf for Respondent at 18, Dunlop v. Bachowski, 421 U.S. 560 (1975).

27. If the complainant is successful and the Secretary brings the Title IV suit, the union must suffer the expense of defending the ralidity of its election and, sometimes, its established procedures for conducting elections. Cf. Krulikowsky v. Metropolitan Dist. Council of Philadelphia, 270 F. Supp. 122, 124 (E.D. Pa. 1967) (national labor union 
avoid the expense and risks of litigation. The legal remedy demanded by Bachowski plaintiffs will generally require that suit be brought after the statutory limitations period of 60 days (from the date of the original complaint) has elapsed. ${ }^{28}$ Since the 60-day limitation period was established for the protection of the union and its officers, the complainant's remedy necessarily involves a statutory right of the union-either the union must waive the limitation or the court must find equitable grounds for extending the period.99 Moreover, the union may be prejudiced in the subsequent trial by certain judicial rulings on issues of law and fact if the reviewing court rejects the Secretary's reasons as "arbitrary and capricious" and the Secretary then brings suit. ${ }^{30}$

Unions have frequently been involved as defendants in suits for judicial review of the Secretary's decisions not to sue. On at least one occasion, the union has intervened as a party defendant. ${ }^{31}$ More significantly, complainants have brought unions into suits for judicial review as named defendants. ${ }^{32}$ Though no union has yet tried to

indispensable party, because plaintiff LMRDA suit challenges section of union's constitution). Moreover, the union's interest is not adequately protected by the Secretary. $C f$. Trbovich v. UMIW, 404 U.S. 528, 538-39 (1972) (main duty of Secretary is to protect public interest).

28. See, e.g., Bachowski v. Brennan, 502 F.2d 79, 82 (3d Cir. 1974), rev'd sub nom. Dunlop v. Bachowski, 421 U.S. 560 (1975) (plaintiff requesting court, as part of relief, to "direct the Secretary ... to reach an agreement with the union extending the period of time for filing suit to set aside [the] election").

29. See Hodgson v. IPPA, 440 F.2d 1113, 1118-19 (6th Cir.), cert. denied, 401 U.S. 828 (1971). See generally notes 33 \& 34 infra.

30. See, e.g., Bachowski v. Brennan, 413 F. Supp. 147 (W.D. Pa.), appeal dismissed, 545 F.2d 363 (3d Cir. 1976). On remand from the Supreme Court, the district court invalidated the method used by the Secretary to assess the degree to which certain violations "may have affected the outcome" of elections where the violations are purely technical. Since the court in a Title IV suit (the same court as that which reviews the Secretary's decision not to sue) must overturn the election if violations "may have affected [its] outcome," 29 U.S.C. $\$ 482(c)(2)(1970)$, this novel judicial determination could be highly prejudicial to the union if the Secretary were ultimately to bring suit.

31. Valenta v. Brennan, 90 L.R.R.M. 3313, 3316 (N.D. Ohio 1975), appeal dismissed, No. 76-1122 (6th Cir. Feb. 24, 1977) (United Steelworkers intervening as defendant).

32. For cases before Bachowski in which unions were named defendants, see the complaints filed in Bibbs v. Brennan, No. 74-1562 (C.D. Cal. Aug. 1, 1974); Casey v. Brennan, No. 73-0836 AVZ (N.D. Cal. Oct. 19, 1973); Rollins v. UMW (Brennan), No. 1753-73 (D.D.C. Sept. 18, 1973); Feltman v. Brennan, No. 73-4823 S (N.D. Ala. Sept. 5, 1973). See also U.S. DeP'T of LABor, CoMpliance, ENForcemext \&. Reporting in 1969 Under the Labor-Management Reporting and Disclosure Act 63 (describing unreported case in which complainant sued both union and Secretary to invalidate stipulated settlement of Title IV suit); U.S. DeP'T OF LABor, Summary of Operations 32 (1965) (describing unreported case in which complainant sued both union and Secretary to enjoin violations of LMRDA and to compel filing of Title IV suit).

For cases filed or decided after Bachowski in which unions have been named defendants, see the complaints filed in Nichols v. Usery, No. 3-76-1007 (N.D. Tex. Jan. 13, 1977); Bachowski v. Brennan, 413 F. Supp. 147 (W.D. Pa.), appeal dismissed, 545 F.2d 
withdraw from these suits, it might be precluded from doing so because it is a "person needed for just adjudication" under Rule 19 of the Federal Rules of Givil Procedure. ${ }^{33}$

A second major goal of Title IV was to avoid protracted governmental investigation into internal union affairs. This prompted the requirement that the Secretary bring suit against the union within 60 days of the filing of the member's complaint with the Labor Depart-

363 (3d Cir. 1976); Hamada v. Secretary of Labor, No. 70-0011 (D. Hawaii Feb. 2, 1976); Fletcher v. Dunlop, 91 L.R.R.M. 2113 (N.D. Ill. 1975), appeal dismissed, No. 76-1450 (7th Cir. Sept. 24, 1976); Rohs v. Usery, No. 77-102 (E.D.N.Y., filed Jan. 17, 1977). It appears that Bachowski plaintiffs sometimes bring unions into the suit as named defendants because they fear that the unions improperly influence the Secretary's decision. See Motion to Vacate Judgment, Fletcher v. Dunlop, 91 L.R.R.M. 2113 (N.D. Ill. 1975) (alleging an agreement whereby the union promised to forego a nationwide railway strike in return for the Secretary's promise not to bring suit); Bachowski v. Brennan, 405 F. Supp. 1227, 1233-34 (W.D. Pa. 1975) (alleging that the "real" reason behind Secretary's decision not to sue was that "the Labor Department plays 'footsie' with the labor establishment to the disadvantage of 'rebels' such as plaintiff').

Although no court has yet explicitly addressed the issue, the courts' authority to join unions as defendants probably rests on the doctrine of ancillary jurisdiction, for there is no independent statutory basis for jurisdiction over defendant unions. See Fraser, Ancillary Jurisdiction of Federal Courts of Persons Whose Interest May Be Impaired If Not Joined, 62 F.R.D. 483, $485-87$ (1974) (ancillary jurisdiction embraces parties joined under FED. R. Civ. P. I9(a)(2)(i)); Jacobs v. United States, 367 F. Supp. 1275, 1277-79 (D. Ariz. 1973) ("Ancillary jurisdiction is the broader concept allowing a court to acquire control of an entire controversy-both the claims and the additional parties-where it has no independent jurisdiction over one $\mathrm{rr}$ more parties.") Plaintiffs, moreover, can obtain effective service of process on both union defendants and the Secretary despite the narrow language of 28 U.S.C. $\$ 1391(\mathrm{e})$ (1970). Cf. Powelton Civic Home Owners Ass'n v. HUD, 284 F. Supp. 809, 833 (E.D. Pa. 1968) ("[T] The requirement [of $\$ 1391(e)]$ that 'each defendant' be a federal defendant refers only to defendants who are beyond the forum's territorial limits." (emphasis in original)); Scott v. Parham, 69 F.R.D. 324, 327-28 (N.D. Ga. 1975) (following Powelton).

33. See, e.g., Local 329, Int'l Longshoremen's Ass'n v. South Atl. \& Gulf Coast Dist., Int'l Longshoremen's Ass'n, 295 F. Supp. 599, 601 (S.D. Tex. 1968) (even when plaintiff and defendant agreed to dismiss defendant from suit, court refused, holding that "[u]nder Rule 19(a) . . . a court must order the joinder of certain designated persons if joinder is feasible"). There are at least two bases for finding the union to be a person needed for just adjudication under FED. R. Civ. P. 19. First, in the union's absence, "complete relief" cannot be guaranteed the complainant within the meaning of FED. $R$. Civ. P. 19 (a)(1). The complete relief in a Bachowski suit is the bringing of the Title IV suit by the Secretary, Bachowski v. Usery, 545 F.2d 363 (3d Cir. 1976); but the Secretary cannot bring suit after the 60-day limitation period unless the union waives its statutory rights. See note 34 infra; Hodgson v. IPPA, 440 F.2d 1113, 1119 (6th Cir.), cert. denied, 404 U.S. 828 (1971). If the union refuses to waive its statutory rights (a natural reaction), the court would either have to dismiss the suit or adjudge the 60-day limit tolled by the Secretary's errors. But it is improper to consider the latter course unless the court joins the union so that the union can present objections and defend its unique interest in the limitation period. Cf. Bradley v. School Bd., 51 F.R.D. 139 (E.D. Va. 1970) (court mandating joinder of new defendants in order to broaden the range of possible remedies and to ensure efficacy of remedies, despite defendant's objections). Second, a Bachowski plaintiff can join the union under FED. R. Civ. P. 19(a)(2)(i) by showing that the union's absence from the suit may "as a practical matter impair or impede [the union's] ability to protect that interest." See Fraser, supra note 32, at 485-86. ("Thus, a person who could but fails to intervene under Rule 24(a)(2) can be made a party to the action against his will under Rule 19(a)(2)(i).") See also notes 27 \& 30 supra. 
ment. ${ }^{34}$ The purpose of this limitation period, as the Supreme Court recognized in Bachowski, was to effect "expeditious resolution of postelection dispute" $3 \overline{0}$ and "to settle as quickly as practicable the cloud on incumbents [sic] title to office." "3e That is, if the Secretary finds no actionable violations, intrusion into union affairs does not extend beyond a two-month period. ${ }^{37}$

Judicial review has contravened this statutory goal simply because judicial review takes so long. Before Bachowski, several courts had reviewed the Secretary's decisions not to sue, invoking a scope of review similar to that which Bachowski prescribed. Even this minimal level of judicial scrutiny required seven to 21 months. ${ }^{38}$ Most actions seek-

34. LMRDA $\$ 402(b), 29$ U.S.C. $\$ 482(b)$ (1970). Senator Kennedy, the Senate sponsor of the Act, intended to set up a rigorous time schedule for the processing of election complaints, believing that "time is of the essence" in resolving post-election disputes. S. REP. No. 1684, 85th Cong., 2d Sess. 13 (1958), reprinted in Legrscative History, supra note 1 , at 701 . The bill as introduced in 1958 required the Secretary to file suit within 30 days of receiving the complaint. S. 3974, 85th Cong., 2d Sess. $\$ 302(\mathrm{~b})$ (1958). Debate in the Senate considered a more flexible provision. Finally, a compromise amendment was accepted, by which the limitation period was extended to 60 days. See 104 CoNG. REC. 11003, 11182 (1958) (Sens. Smith \& Kennedy), reprinted in LegrsLative History, supra note 1 , at $710-11$.

Courts have allowed the Secretary to bring suit after the expiration of the 60-day period if the union voluntarily agrees to an extension. Such extensions are granted in many cases where the Secretary finds actionable violations in order that the union and Secretary might negotiate an out-of-court settlement agreement. Hodgson v. Lodge 851, IAM, 454 F.2d 545, 551-53 (7th Cir. 1971); Hodgson v. IPPA, 440 F.2d 1113 (6th Cir.), cert. denied, 404 U.S. 828 (1971); see Note, Waivers of the LMRDA $\$ 402(b)$ 60-Day Time Limit: When Must the Secretary of Labor Sue to Set Aside a Union Election?, 1971 Duke L.J. 1199. Courts have also tolled the 60-day limitation period when the union has obstructed the Secretary's investigation. Brennan v. Independent Lift Truck Builders Union, 490 F.2d 213, 216 (7th Cir. 1974); Hodgson v. Local 610, United Elec., Radio \& Machine Workers, 342 F. Supp. 1344, 1347 (W.D. Pa. 1972). Since the 60-day limitation period is largely a protection for the union, its benefits may be fairly waived by the union's consent or unlawful obstruction.

Congress's concern for speedy resolution of post-election disputes is also evident in the requirement that the union member file his complaint with the Secretary within one month of exhausting union remedies or within four months of lodging his complaint with the union, whichever is shorter. LMRDA $\$ 402(a), 29$ U.S.C. $\$ 482$ (a) (1970). The rationale for this provision is plain: "Since time is of the essence, no complaint may be entertained which is filed [after the statutory period]." S. REP. No. 187, 86th Cong., 1st Sess. 21 (1959), reprinted in Legislative History, supra note 1, at 778 (emphasis added).

35. 421 U.S. at 575.

36. Id. at $\mathbf{5 7 3 .}$

37. Even if the Secretary finds actionable violations, the two-month limitation period protects the union by giving it early notice of the suit and an opportunity to remedy the violations voluntarily. However, it must be noted that once actionable violations are found, unions frequently agree to extensions beyond the statutory period in order to pursue negotiations with the Secretary. See Note, Union Elections and the LMRDA: Thirteen Years of Use and Abuse, 81 YALE L.J. 407, 573 (1972) (Appendix D) (average suit filed seven months after the challenged election, despite fact that exhaustion of internal remedies and 60-day limitation period usually require only four to six months).

38. See DeVito v. Shultz, 72 L.R.R.M. 2682 (D.D.C. 1969), described in U.S. DEp'T of Labor, Compliance, Enforcement \& Reporting in 1970 Under the Labor-Management 
ing judicial review that have been filed or decided since Bachowsk $i^{39}$ have been equally time-consuming. Several cases have lasted more than a year; after four years Bachowski itself is still tied up in the courts. ${ }^{40}$

There are several reasons for this lengthy review process. District courts' dockets are crowded. ${ }^{41}$ Once begun, such suits often involve time-consuming litigation over complainants' discovery rights. ${ }^{42}$ If the

Reporting AND Disclosure ACr 59-60 (lapse of seven months between commencement of suit and final dismissal of complaint); Schonfeld v. Wirtz, 258 F. Supp. 705 (S.D.N.Y. 1966), described in U.S. DEP'T OF LABOR, COMPLIANCE, ENFORCEMENT \& REPORTING in 1968 UNDER the Labor-Management Reporting and Disclosure Act 48 (lapse of 21 months). See also U.S. Dep't of Labor, CoMplance, Enforcement \& Reporting in 1969 UNder the LaboRManagement Reporting and Disclosure Act 63 (lapse of $191 / 2$ months in unreported case).

39. Only three cases decided under Bachowski have been reported: Bachowski v. Brennan, 413 F. Supp. 147 (W.D. Pa.), appeal dismissed, 545 F.2d 363 (3d Cir. 1976) (holding Secretary's supplemented reasons statement "arbitrary and capricious" and remanding to Secretary for further consideration); Fletcher v. Dunlop, 91 L.R.R.M. 2113 (N.D. Ill. 1975), appeal dismissed, No. 76-1450 (7th Cir. Sept. 24, 1976) (complaint dismissed, finding Secretary's statement of reasons not arbitrary on its face); Valenta $v$. Brennan, 90 L.R.R.M. 3313, 3316 (N.D. Ohio 1975), appeal dismissed, No. 76-1122 (6th Cir. Feb. 24, 1977) (complaint dismissed because Secretary's reasons statement, though unresponsive to complainant's objections, not arbitrary on its face). Unreported cases include the following: Nichols v. Usery, Civ. No. 3-76-1007 (N.D. Tex. Jan. 13, 1977) (complaint dismissed); Woodall v. Usery, Civ. No. 3-76-271 (S.D. Ohio Dec. 10, 1976) (same); Riggi v. Department of Labor, Civ. No. 75-1922 (D.N.J. Oct. 5, 1976) (same); Dennis v. Secretary of Labor, Civ. No. 76.898 (D. Md. June 25, 1976) (dismissed on motion of petitioner); Rancich v. Secretary of Labor, Civ. No. 76-784 S (W.D. Wash. Apr. 29, 1976) (dismissed); Hamada v. Secretary of Labor, Civ. No. 76.0011 (D. Hawaii Feb. 2, 1976) (stipulation for dismissal with prejudice); Dycus v. Dunlop, No. 75-2873 IH (C.D. Cal. Jan. 16, 1976) (complaint dismissed); Keller v. Brennan, Civ. No. 74-327 (M.D. La. Dec. 20, 1975) (same). At least two cases are still pending: Rohs v. Usery, Civ. No. 77-102 (E.D.N.Y., filed Jan. 17, 1977) (no action as of May 1977); Fennelly v. Dunlop, Civ. No. 75-1764 F (D. Mass., filed May 5, 1975) (lengthy discovery litigation).

40. A schedule of the cases filed or decided after Bachowski, see note 39 supra, is as follows:

$\begin{array}{ll} & \text { DATE OF FI } \\ \text { SUIT } & \text { SEEKING JUD } \\ \text { Rohs } & \text { Jan. 17, 1977 } \\ \text { Fennelly } & \text { May 5, 1975 } \\ \text { Bachowski } & \text { Nov. 8, 1973 } \\ \text { Valenta } & \text { Jan. 7, 1974 } \\ \text { Nichols } & \text { July 29, 1976 } \\ \text { Woodall } & \text { Aug. 20, 1976 } \\ \text { Riggi } & \text { Nov. 10, 1975 } \\ \text { Flelcher } & \text { Sept. 15, 1975 } \\ \text { Dennis } & \text { June 15, 1976 } \\ \text { Rancich } & \text { Apr. 26, 1976 } \\ \text { Hamada } & \text { Jan. 15, 1976 } \\ \text { Dycus } & \text { Aug. 26, 1975 } \\ \text { Keller } & \text { Dec. 2, 1974 }\end{array}$

FINAL DISPOSITION OF CASE (AS OF MAY 1977)

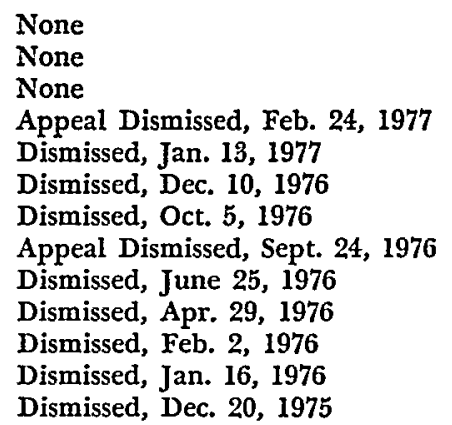

41. See generally P. Bator, P. Mishkin, D. Shapiro \& H. Wechsler, Hart \& Wechsler's

The Federal Courts aNd The Federal SYstem 49-55 (2d ed. 1973).

42. For example, consider the history to date of Fennelly v. Dunlop, Civ. No. 75-1764 F

(D. Mass., filed May 5, 1975):

July 3, 1975 - Defendant's Motion for Summary Judgment 
reviewing court asks the Secretary for a supplemental statement of reasons, a further delay of several months ensues. ${ }^{43}$ Finally, since the standards of review set forth in Bachowski are not fully defined and since the reviewing court is a district court, complainants sometimes appeal adverse decisions. ${ }^{44}$

\section{B. Inadequate Protection for Complainant's Interest}

The Supreme Court in Bachowski held that the reviewing court must confine its scrutiny to the Secretary's statement of reasons for declining to sue, inasmuch as a de novo factual inquiry would contravene the objectives of Title IV. ${ }^{4 \overline{5}}$ Because this scope of review is so narrow, because there is some question whether the reviewing court can compel the Secretary to bring suit, and because Title IV litigation entails special time pressures, judicial review under Bachow$s k i$ has been little better for complainants than no review at all. ${ }^{46}$

July 21, 1975 - Plaintiff's Request for Production of Documents

Aug. 20, 1975 - Defendant's Motion for Protective Order

Sept. 4, 1975 - Plaintiff's Opposition to Defendant's Motion for Protective Order

Sept. 11, 1975 - Protective Order Granted by Court

No further formal action has been taken on this case as of May 1977.

43. The timetable of filings in Valenta v. Brennan, 90 L.R.R.M. 3316 (N.D. Ohio 1975), appeal dismissed, No. 76-1122 (6th Cir. Feb. 24, 1977), is suggestive:

Jan. 7, 1974 - Plaintiff files complaint for judicial review of Secretary's failure to bring suit.

July 3, 1974-Court directs Secretary to file a more complete statement of reasons.

Aug. 1, 1974 - Secretary files supplemental statement.

Jan. 23, 1975 - Court directs Secretary to respond to further questions.

June 19,1975 - Court orders Secretary to file another supplemental statement.

July 29, 1975 - Secretary files supplemental statement.

Nov. 11, 1975 - Court reluctantly accepts Secretary's reasons under Bachowski.

Bachowski is another case in which the litigation has dragged on owing to the nced for supplemental statements of reasons. The case was remanded to the district court in 1975. On December 19, 1975, the court demanded a supplemental reasons statement, which the Secretary filed on March 30, 1976. On May 7, 1976, the court remanded to the Secretary to recalculate the effects of the violations on the outcome of the election. Bachowski v. Brennan, 413 F. Supp. 147 (W.D. Pa. 1976). The Secretary appealed the court's order remanding the case, but the Third Circuit dismissed the appeal because the order was not "final." Bachowski v. Usery, 545 F.2d 363 (3d Cir. 1976). Plaintiff then filed a motion for summary judgment in the district court. On February 4, 1977, the Secretary filed an opposition to plaintiff's motion for summary judgment. The court has not yet ruled on the plaintiff's motion.

44. Plaintiffs appealed district court dismissals in Fletcher v. Dunlop, 91 L.R.R.M. 2113 N.D. Ill. 1975), appeal dismissed, No. 76-1450 (7th Cir. Sept. 24, 1976); and Valenta v. Brennan, 90 L.R.R.M. 3316 (N.D. Ohio 1975), appeal dismissed, No. 76-1122 (6th Cir. Feb. 24, 1977).

45. See p. 890 supra.

46. There are three possible advantages to judicial review under Bachowski, though they seem insubstantial in practice. The Bachowski Court argued that requiring a reasons statement subject to judicial review "promotes thought by the Secretary and compels him to cover the relevant points and eschew irrelevancies." 421 U.S. at 572. But cf. Valenta v. Brennan, 90 L.R.R.M. 3316 (N.D. Ohio 1975), appeal dismissed, No. 76-1122 
Review under Bachowski is inadequate because the Labor Department's statement of reasons, drawn up after a decision is made and sometimes supplemented in court, is a "record" that is insufficient for meaningful review under the narrow "arbitrary and capricious" test. ${ }^{47}$ The statement of reasons the Secretary presents to the reviewing court is potentially self-serving and generally conclusory. ${ }^{48}$ Absent a full administrative record, with opportunity for interested parties to present their evidence and views, limited judicial review can be no more than a formality; courts should be reluctant to give their imprimatur to agency decisions supported only by the agency's own factual conclusions. ${ }^{49}$ Similarly, the complainant seeking judicial re-

(6th Cir. Feb. 24, 1977) (court dissatisfied with the Secretary's failure to be responsive to complainant's assertions but affirmed his decision under Bachowski). Second, judicial review might stimulate the Labor Department to adopt new procedures to give complainants a chance to present their point of view. Most convincing is the argument that the reviewing court can examine standards of law applied by the Secretary. See, e.g., Bachowski v. Brennan, 413 F. Supp. 147 (TV.D. Pa.), appeal dismissed, 545 F.2d 363 (3d Cir. 1976) (overturning Secretary's method of computing effect that violations of right to secret ballot may have had on the outcome of the election). However, because most complaints after Bachowshi have raised purely factual issues, see note 50 infra, this function of judicial review is of limited significance. Morcover, the judicial decisions in Title IV trials and judicial review of departmental rulemaking provides a judicial check on the Secretary's interpretations of Title IV.

47. Courts have found that there can be no meaningful review of informal decisions unless the decision is supported by a formal agency record, a thorough explanation of the decision by the agency, or an in-depth inquiry by the court. See Citizens to Preserve Ovcrton Park, Inc. v. Volpe, 401 U.S. 402, 415, 420 (1972) (review must be based on the "full administrative record that was before the Secretary at the time he made his decision"); D.C. Federation of Civic Ass'ns v. Volpe, 459 F.2d 1231, 1237-38 (D.C. Cir. 1971), cert. denied, 405 U.S. 1030 (1972); National Rifle Ass'n v. United States Postal Serv., 407 F. Supp. 88, 91 (D.D.C. 1976) ("[T] he court cannot properly apply a limited standard of review of administrative decisions without the assurance of an impartial and thorough-going review by the administrative decisionmaker, with a record that reflects a full opportunity for interested parties to present their evidence, and to rebut unfarorable cvidence introduced by the agency.")

48. The statement of reasons in Dunlop v. Bachowski, 421 U.S. 560, 578-90 (1975), summarizes the election violations and the number of votes that may have been affected by each violation. The statement is conclusory in that the facts alleged are not accompanied by documentary evidence to indicate the sources of the Secretary's factual conclusions. Moreover, the statement fails to state reasons why the Secretary rejected many of the allegations posited in Bachowski's original complaint. Cf. Valenta v. Brennan, 90 L.R.R.M. 3316 (N.D. Ohio 1975), appeal dismissed, No. 76-1122 (6th Cir. Feb. 24, 1977) (criticizing Secretary's supplemental statements as unresponsive to complainant's objections, yet affirming Secretary's decision pursuant to Bachowski). By ignoring the complainant's factual queries and tailoring factual findings to the final decision, the Secretary could inadvertently evade review altogether.

49. When judicial review is limited to examination of an agency's decision for "abuse of discretion" or "arbitrary and capricious" action, the reviewing court generally will look only at the agency record. See Camp v. Pitts, 411 U.S. 138, 142 (1973). However, when the agency's procedures are inadequate to establish a record suitable for judicial review, the court should remand to the agency for a more complete record. See, e.g., Citizens to Preserve Overton Park, Inc. v. Volpe, 401 U.S. 402, 415 (1972); Hooker Chems. \& Plastics Corp. v. Train, 537 F.2d 620, 636-37 (2d Cir. 1976); National Rifle 
view fails to receive a meaningful hearing for his grievance unless the court has before it a full record disclosing the grounds for the agency's decision, as well as the arguments rejected by the agency. Indeed, most plaintiffs have pressed preeminently factual challenges, which are beyond Bachowski's narrow scope of review. jo

The cases for judicial review that have been brought or decided since Bachowsk $i^{\mathrm{si}}$ illustrate the practical inadequacy of this narrow scope of review. The suits establish the following pattern: The union member files a complaint alleging that the Secretary relied on inaccurate facts or refused to sue for improper reasons. The Secretary asserts that the violations did not affect the outcome of the election and that his reasons, as reflected in his written statement, are rational. The complainant files motions for discovery, and the Secretary files a motion for a protective order. All parties file motions for summary judgment. The court ultimately (sometimes after obtaining a supplemental statement from the Secretary) dismisses the suit, and the complainant sometimes appeals. In three major cases plaintiffs presented colorable factual arguments, only to have the court dismiss the complaint because the Secretary's statement of reasons was not irrational on its face..$^{52}$ In Valenta $v$. Brennan, ${ }^{53}$ for example, the reviewing court demanded supplemental reasons in the face of the complainant's extensive rebuttal of the factual bases of the Secretary's first statement.

Ass'n v. United States Postal Serv., 407 F. Supp. 88, 91 (D.D.C. 1976). See McCormack, The Purpose of Due Process: Fair Hearing or Vehicle for Judicial Review?, 52 TEx. L. REv. 1257, 1258, 1301-02 (1974); Nathanson, Probing the Mind of the Administrator: Hearing Variations and Standards of Judicial Review under the Administrative Procedure Act and Other Federal Statutes, 75 CoLum. L. REv. 721 (1975).

50. That is, complainants and the Secretary mainly disagree, not on points of law, but on findings of fact. Complainants in the three reported cases decided under Bachowski raised mainly factual questions. See Valenta v. Brennan, 90 L.R.R.M. 3316 (N.D. Ohio 1975), appeal dismissed, No. 76-1122 (6th Cir. Feb. 24, 1977) (conflicting evidence whether certain violations occurred); Plaintiff's Memorandum in Opposition to Defendants' Motion for Summary Judgment, Fletcher v. Dunlop, 91 L.R.R.M. 2113 (N.D. Ill. 1975) (alleging that Secretary failed to investigate violations noted in original complaint); Bachowski v. Brennan, 405 F. Supp. 1227 (W.D. Pa. 1975) (plaintiff alleged improper motivation of Secretary and the Department's failure to consider all relevant evidence).

51. See note 39 supra.

52. See Dycus v. Dunlop, No. 75-2873 IH (C.D. Cal. Jan. 16, 1976); Fletcher v. Dunlop, 91 L.R.R.M. 2113 (N.D. Ill. 1975), appeal dismissed, No. 76-1450 (7th Cir. Sept. 24, 1976); Valenta v. Brennan, 90 L.R.R.M. 3313, 3316 (N.D. Ohio 1975), appeal dismissed, No. 76-1122 (6th Cir. Feb. 24, 1977). Cf. Usery v. Local 639, Teamsters, 543 F.2d 369 (D.C. Cir. 1976) (applying Bachowski standard of review to uphold Secretary's certification of rerun election, despite factual issues raised by intervenors); Usery v. Dist. 22, UMW, 93 L.R.R.M. 2364 (D. Utah 1976) (similar).

53. 90 L.R.R.M. 3316 (N.D. Ohio 1975), appeal dismissed, No. 76-1122 (6th Cir. Feb. 24, 1977). 
The court remained dissatisfied with the revised set of reasons but felt powerless under Bachowski to do more:

[T] he court is not permitted to resolve the conflict between the Secretary's findings and plaintiff's conflicting and plausible statements, even though the Secretary fails to address himself to some points raised by Valenta that on this record seem to warrant analysis. ... On the present record the plaintiff has not proved that the Secretary is acting arbitrarily ... . But the failure of the Secretary to challenge these statements is disturbing. ${ }^{54}$

In only one of the post-Bachowski cases has a reviewing court found the Secretary's statement of reasons "so irrational as to be arbitrary and capricious." This was the district court in Bachowski itself, which, on remand from the Supreme Court and the Third Circuit, invalidated the Secretary's method of computing the effects of election violations as internally inconsistent. This decision, resting on narrow and questionable legal grounds, is exceptional..$^{55}$ In general, the heavy judicial

54. Id. at 3323. In Fletcher v. Dunlop, 91 L.R.R.M. 2113 (N.D. Ill. 1975), appeal dismissed, No. 76-1450 (7th Cir. Sept. 24, 1976), the court entered summary judgment in favor of the Secretary and the union, 91 L.R.R.M. at 2113-14, despite the plaintiff's contentions that the Secretary misinterpreted the union's constitution and failed to investigate material violations alleged in the complaint, Plaintiff's Memorandum in Opposition to Defendants' Motion for Summary Judgment at 1-4, Fletcher v. Dunlop, 91 L.R.R.M. 2113 (N.D. Ill. 1975).

What internal union remedies exist to challenge a union election and whether a grievant has exhausted these remedies that do exist are matters of simple fact. The Secretary of Labor has no special knowledge and discretion with respect to their determination. The Court can and should make its own independent findings of fact on these issues and not merely review the Secretary's findings to determine if they are arbitrary and capricious.

Motion to Vacate Judgment at 3, Fletcher v. Dunlop, 91 L.R.R.M. 2113 (N.D. Ill. 1975). Cf. Bibbs v. Brennan, No. 74-1562 (C.D. Cal. Aug. 1, 1974) (finding clear error of fact in Secretary's interpretation of union constitution and reversing Secretary's decision concerning rules of election rerun under Title IV).

55. In so doing, the court may have evinced some restiveness with the Supreme Court's decision by applying the "arbitrary and capricious" standard in a somewhat unorthodox manner. In calculating the effect that violations may have had on the outcome of the election, the Secretary distinguished between "cases where the number of votes affected can be ascertained with some certainty, and cases where it can not." Bachowski v. Brennan, 413 F. Supp. 147, 149 (W.D. Pa.), appeal dismissed, 545 F.2d 363 (3d Cir. 1976). The Secretary explained that with violations of the latter type, "it is impossible to prove one way or the other if any voters were actually intimidated by such violations." Id. The Secretary reasonably concluded that it would be illogical to say that these violations may have affected the outcome of the election with the same probability as the violations "when the impact on such votes was directly affected by a violation and the number of such votes could be measured with some certainty." Id. Moreover, the Secretary noted that "substantive violations of a type which may affect how a voter votes are to be distinguished from merely technical violations of a procedural character." Id. at 150 (emphasis in original). However, the court rejected the Secretary's distinction in this case and remanded to the Secretary to recalculate the effect that the violations may have had on the outcome of the election. Id. at 151 . 
presumption in favor of the Secretary's decision and the lack of any factual investigation have foreclosed meaningful judicial scrutiny of the Secretary's statement of reasons. Such foreshortened judicial review affords meager recognition of the complainants' actual objections.

The second limitation inherent in judicial review under Bachowski is that a reviewing court which finds the Secretary's reasons arbitrary can do no more than remand for additional reasons. Although the Bachowski Court purported to leave open the question whether the reviewing court can compel the Secretary to bring suit,"50 such compulsion appears clearly beyond the judicial power as a matter of statutory and constitutional law. First, such judicial coercion would conflict with the statutory scheme. Courts have repeatedly recognized Congress's reliance on the "special knowledge and discretion" of the Labor Department in making decisions to bring Title IV actions. ${ }^{57}$ The Bachowski Court explicitly held that the reviewing court is "not authorized to substitute its judgment for the decision of the Secretary not to bring suit." "s8 Yet the Court only conceded that the congressional reliance on the Secretary's discretion "presents some difficulty" for the view that suit may be compelled. ${ }^{59}$ At least one circuit court

Despite the Secretary's reasonable explanation for his method of computation, the court substituted its own judgment for that of the Secretary, seemingly contrary to the Supreme Court's admonition in Bachowski. 421 U.S. at 575.

Another court has suggested even greater willingness to go beyond Bachowski and expand the role of the reviewing court. In Usery v. Local 639 , Teamsters, 543 F.2d 369, 379 (D.C. Cir. 1976), the D.C. Circuit suggested (in dictum) that

where the Secretary's statement on its face indicates a rationally based decision the court's task is at an end, unless the challenger makes a specific factual proffer of irregularity, in which event the burden of persuasion shifts to the Secretary to provide further supplementation (the ultimate burden of proof resting with the challenger). This conclusion seems contrary to Bachowski's holding that "review beyond the confines of the reasons statement" would be justified only where the Secretary's decision is " 'plainly beyond the bounds of the Act [or] clearly defiant of the Act." 421 U.S. at 574 (quoting DeVito v. Shultx, 72 L.R.R.M. 2682, 2682 (D.D.C. 1969)).

56. 421 U.S. at 575-76. But see $i d$. at 592 (Rehnquist, J., dissenting) (claiming that Court's logic answered "reserved" question in affirmative). The Court assumed that the Secretary would "act appropriately" if a court overturned his reasons for not bringing suit. However, there are occasions where the Secretary would be forced to defy the court and refuse to bring suit even when the court overturned his statement of reasons. See, e.g., Bachowski v. Usery, 545 F.2d 363, 373 (3d Cir. 1976) (suggesting that Secretary could get review of interlocutory district court rulings by refusing to bring suit and appealing any order compelling suit).

57. Calhoon v. Harvey, 379 U.S. 134, 140 (1964) (emphasis added); see note 6 supra.

58. 421 U.S. at $\mathbf{5 7 1 .}$

59. Id. at 575. See Work v: United States ex rel. Rives, 267 U.S. 175, 177-78 (1925); Byse \& Fiocca, Section 1361 of the Mandamus and Venue Act of 1962 and "Nonstatutory" Judicial Review of Federal Administrative Action, 81 HARv. L. REv. 308, 334-36, 348-49 (1967). Since the Secretary's statutory discretion is limited by the Constitution and the LMRDA, a different question is whether courts can enjoin agencies from following unlawful rules or regulations. See Davis Associates, Inc. v. Secretary of HUD, 498 F.2d 385, 389 n.5 (Ist Cir. 1974); Adams v. Richardson, 480 F.2d 1159, 1162 (D.C. Cir. 1973). 
has clearly disapproved judicial compulsion of suit as violating the goals of Title IV. ${ }^{60}$ In light of the discretion vested in the Secretary by Title IV, this conclusion appears correct.

Second, compelling suit would violate principles of separation of powers. Article II vests the power to "execute" the laws in the Executive Department, not the federal judiciary. ${ }^{61}$ Cases considering judicial review of prosecutorial discretion have repeatedly distinguished between legitimate judicial review setting forth the limits of agency discretion and invalid judicial usurpation of executive decisionmaking functions. ${ }^{62}$ Such judicial decisionmaking would be especially prob-

60. Howard v. Hodgson, 490 F.2d 1194, 1196-97 (8th Cir. 1974).

61. U.S. CoNsT. art. III, $\S 2$. One recent case illustrates the principle that Article III courts cannot perform Article II functions under the guise of judicial review. In Billiteri v. United States Bd. of Parole, 400 F. Supp. 402,409 (W.D.N.Y. 1975), rev'd, 541 F.2d 938 (2d Cir. 1976), the district court issued an order compelling the Parole Board to release a prisoner on parole, because the Board's reasons for refusing to do so were "arbitrary and capricious." See also Billiteri v. United States Bd. of Parole, 385 F. Supp. 1217 (W.D.N.Y. 1974) (reversing arbitrary decision reached by Board and remanding to Board for further consideration). The Second Circuit reversed and vacated the order: "As a statutory court, the United States District Court had no power to conduct such a [parole] proceeding and issue such an order. Congress has vested in the sound discretion of the Parole Board the sole power to grant or deny parole." Billiteri v. United States Bd. of Parole, 541 F.2d 938, 944 (2d Cir. 1976). Billiteri is especially suggestive in a Title IV context, for the district court in Billiteri was operating under a standard of judicial review that permits factual inquiry. Cf. Nader v. Saxbe, 497 F.2d 676, 679 n.18 (D.C. Cir. 1974) (reviewing court should not compel Executive Department to prosecute particular cases).

62. See, e.g., Nader v. Saxbe, 497 F.2d 676 (D.C. Cir. 1974), cited in Dunlop v. Bachowski, 421 U.S. 560, 576 (1975) (holding prosecutorial decisions reviewable but denying plaintiffs standing in instant case). The circuit court noted that the complaint did "not ask the court to assume the essentially Executive function of deciding whether a particular alleged violator should be prosecuted." Id. at 679 .

To mandamus a particular prosecution, a court would have to determine that no legitimate consideration informed the prosecutor's decision not to prosecute the individual in question. Such a determination would normally be very difficult, for a prosecutor may lawfully take account of many factors other than probable cause in making such decisions. . . . That the balancing of these permissible factors in individual cases is an executive, rather than a judicial, function follows from the need to keep the courts as neutral arbiters in the criminal law generally ... and from Art. II, $\S 3$ of the Constitution, which charges the President to "take Care that the Laws be faithfully executed"...

Id. at 679 n.18.

The Executive's constitutional duty to "take Care that the Laws be faithfully exccuted," Art. II, $\$ 3$, applies to all laws, not merely to criminal statutes ..... It would seem to follow that the exercise of prosecutorial discretion, like the exercise of Executive discretion generally, is subject to statutory and constitutional limits enforceable through judicial review. . . The law has long recognized the distinction between judicial usurpation of discretionary authority and judicial review of the statutory and constitutional limits to that authority.

Id. at 679 n.19. Cases reviewing agencies' prosecutorial discretion have confirmed this distinction between courts' invalid usurpation of the prosecutor's discretionary authority and courts' valid check against abuses of prosecutorial discretion. See Adams v. Richardson, $480 \mathrm{~F} .2 \mathrm{~d} 1159,1162$ (D.C. Cir. 1973) (distinguishing order stopping flow of HEW 
lematic under Bachowski, for reviewing courts cannot engage in the factual inquiry that must precede a prosecutor's decision to file suit. ${ }^{03}$

Third, it would be imprudent for courts to force the Secretary to sue when he is genuinely unwilling to do so. Although such a suit would probably not be dismissed for lack of necessary "adversariness," 64 it is likely that the Secretary would be reluctant to pursue the

funds to segregated schools from court order that agency take affirmative prosecutorial action); Medical Comm. for Human Rights v. SEC, 432 F.2d 659, 673-75, 675 n.19 (D.C. Cir. 1970), vacated and remanded on other grounds, 404 U.S. 403 (1972) (SEC has broad discretion in enforcing proxy rules; courts may examine reasons for agency decision not to prosecute but may not dictate outcome of enforcement decisions); NAACP v. Levi, 418 F. Supp. 1109, 1116-17 (D.D.C. 1976) (court has jurisdiction to review allegedly discriminatory policies of Department of Justice); cf. Seiden v. United States, 537 F.2d 867, 870 (6th Cir. 1976) (Attorney General's decisions not to defend individuals under Federal Drivers Act can be reviewed by courts, but courts cannot mandate Attorney General to defend under the Act).

Commentators arguing for greater judicial review of prosecutorial discretion generally have failed to distinguish between judicial review of decisions not to prosecute and judicial compulsion of prosecution in individual cases. See, e.g., Cox, Prosecutorial Discretion: An Overview, 13 AM. CrIM. L. REv. 383 (1976); Note, Reviewability of Prosecutorial Discretion: Failure to Prosecute, 75 CoLum. L. REv. 130, 146-61 (1975). But see Comment, The Use of Mandamus to Control Prosecutorial Discretion, 13 Am. Crim. L. Rev. $563,575-76,581-97$ (1976) (courts cannot mandate prosecution of particular individuals because that decision would usurp executive functions of prosecutor). See also note 113 infra.

63. Under Title IV, once the Secretary has determined that violations may have affected an election's outcome, he must decide whether the case is "suitable for litigation." See note 81 infra. This executive judgment involves analysis of the probity of the evidence, the prospects of winning in a particular court, the likelihood of settling the case without litigation, and the allocation of prosecutorial resources. Before a court could compel suit, therefore, it would have to make the difficult determination that "no legitimate consideration informed the prosecutor's decision not to prosecute the individual in question." Nader v. Saxbe, 497 F.2d 676, 679 n.18 (D.C. Cir. 1974) (cmphasis added). Because full factual inquiry is foreclosed by Bachowski, the court could make this determination only by requiring the Secretary to issue new supplemental statements whenever it was dissatisfied with a particular reason. Yet the Bachowski Court warned that "endless litigation concerning the sufficiency of the written statement is inconsistent with the statute's goal of expeditious resolution of post-election disputes." 421 U.S. at 575.

64. The Bachowski Court reserved decision on whether a judicially-compelled suit would lack the requisite "adversity of interest" to constitute an Article III "case or controversy," 421 U.S. at 575 n.12. Several cases indicate that constitutional problems might arise if the Secretary sued while persisting in the belief that the violations did not affect the election's outcome. See Moore v. Charlotte-Mecklenburg Bd. of Educ., 402 U.S. 47 (1971) (no constitutional "case or controversy" if both litigants desire same outcome); United States v. Johnson, 319 U.S. 302 (1943) (no Article III "case" if no genuine adversary issue exists between parties); Muskrat v. United States, 219 U.S. 346 (1911) (statute unconstitutional because authorizing a nonadversarial "case" for the federal courts). On the other hand, courts have often avoided this issue by considering the arguments of an amicus curiae or intervenor. See, e.g., Cheng Fan Kwok v. Immigration \&. Naturalization Serv., 392 U.S. 206, $210 \mathrm{n.9}$ (1968) (appointment of amicus). In the context of Title IV, the requisite adversity of interest could be supplied by a complainant intervenor. Cf. Trbovich v. UMW, 404 U.S. 528 (1972) (union member may intervene in Title IV suit brought by Secretary of Labor). 
case vigorously ${ }^{65}$ Moreover, the court is not in a position to monitor the Secretary's performance effectively.

Even if the Secretary ultimately decides to sue, judicial review will have benefited the complainant little because the process is so lengthy. Suits for judicial review under Bachowski have often lasted more than a year, ${ }^{68}$ and the ensuing suit by the Secretary, if the past is any guide, will consume an additional eighteen months. ${ }^{67}$ Since local unions are required by the LMRDA to hold elections every three years, $^{, 8}$ the complainant will have gained, at most, only a moral victory. ${ }^{68}$

\section{A Proposed Restructuring of Title IV Decisionmaking}

The central problem in Title IV litigation, implicit in Bachowski, is how to give complainants meaningful procedural protection for their private interests without contravening Title IV's goal of minimizing governmental intrusion into union affairs. ${ }^{70}$ Judicial review is an inadequate solution but does point to the need for some kind of procedural protection for the legal rights of complainants recognized

65. It would, for example, be within the Secretary's discretion to settle the case with the union out of court. See, e.g., Casey v. Brennan, No. 73-0836 AVZ (N.D. Cal. Oct. 19, 1973) (unsuccessful mandamus action against Secretary, who acted within his discretion in settling Title IV case without filing suit). Even if the Secretary brought suit and the complainant intervened under Trbovich, the Secretary has broad discretion to settle the case without regard to the intervenor's interest. See note 10 supra (listing cases where complainants unsuccessfully challenged Secretary's discretion to enter into settlement agreements).

66. See note 40 supra.

67. According to a Labor Department study conducted for the years 1966-1970, the average Title IV suit took slightly longer than 18 months. U.S. DEP'T OF LABOR, UNION Election Cases Under the Labor-Management Reporting and Disclosure Acts 19661970, at 118 (1972) [hereinafter cited as Union Election CASEs].

68. LMRDA § 402(a), (b), 29 U.S.C. \$ 482(a), (b) (1970).

69. Although hard to gauge, a "moral victory" might yet be substantial where it enhances the prestige of the complainant during the rerun election. Cf. Brennan $v$. United Steelworkers Dist. 31, Civ. No. 73-957B (W.D. Pa. Dec. 2, 1974) (rerun of union district election held $1 / 2$ years after original election won by complainant-intervenor Sadlowski as step in his ultimate quest for the presidency of the Steelworkers).

70. Despite criticisms of the Labor Department's handling of Title IV suits, Congress still recognizes the importance of the Department's screening and expediting functions in processing them. UMW Hearings $I I$, supra note 8, at 3-4 (Sen. Javits), 70-71 (Sen. Taft). Even Senator Robert Griffin, a House sponsor of LMRDA and one of the leading critics of the Labor Department's enforcement of that Act, apparently favors administrative reform that would leave exclusive enforcement of the LMRDA with the Labor Department or "with some other government agency. Id. at 52-53 (colloquy with Sen. Taft). Senator Griffin recognized that the purpose of the LMRDA was "to strike a balance between the rights of individuals and the needs of the union as an institution." Id. at 51. But see Note, supra note 37, at 472-73, 567. 
in Trbovich and Bachowski. ${ }^{71}$ This Note proposes, as a more effective solution, that Congress replace judicial review with procedural reforms within the Labor Department.

Since courts have shown an increasing willingness to provide judicial review for decisions once assumed to be unreviewable, Congress should make explicit its desire to prevent review of agency decisions. ${ }^{72}$ In order to subserve the LMRDA's overarching goal of assuring union democracy with minimal governmental interference, Congress should amend Title IV to preclude judicial review of the Secretary's decision not to sue..$^{73}$

However, in light of the recognition by both Congress ${ }^{74}$ and the

71. Given the fact that the Secretary is the complainant's "lawyer" and that the complainant has a legal interest in the institution of the Title IV suit, the Department should provide procedural protection for complainants' interests. Generally, courts and commentators have recognized the need for procedures whereby individuals have a chance to be heard and to contribute evidence when agencies make decisions that affect their legal interests. See Goldberg v. Kelly, 397 U.S. 254 (1970); National Welfare Rights Organization r. Finch, 429 F.2d 725, $736-38$ (D.C. Cir. 1970); Murphy \& Hoffman, Current Models for Improving Public Representation in the Administrative Process, 28 Av. L. Rev. 391, 393-96 (1976). Specifically, there has been recurring criticism that the Labor Department ignores complainants and their interests when it makes decisions regarding Title IV suits. See p. 899 supra \& notes 74 \& $102-04$ infra.

72. The Administrative Procedure Act (APA) provides that judicial review of final agency action will be denied to the extent that statutes preclude review or the action is committed to agency discretion by law. APA $\$ 10(a), 5$ U.S.C. $\$ 701$ (a) (1970).

However, the Supreme Court has narrowly construed these statutory exceptions to judicial review. Statutory preclusion of review is now established only by "clear and convincing evidence" of such congressional intent. Dunlop v. Bachowski, 421 U.S. 560, 567 (1975); Citizens to Preserve Overton Park, Inc. v. Volpe, 401 U.S. 402, 410 (1971); Abbott Laboratories v. Gardner, 387 U.S. 136, 141 (1967). See generally K. D.Avis, ADministrative LAw of The Sevestiss $\$ 28.09$ (1976); Note, Statutory Preclusion of Judicial Review Under the Administrative Procedure Act, 1976 DukE L.J. 431 (criticizing Supreme Court's approach). Nonreviewability of agency action "committed to agency discretion by law" has been termed "a very narrow exception" that is "applicable in those rare instances where "statutes are drawn in such broad terms that in a given case there is no law to apply.' S. Rep. No. 752, 79th Cong., 1st Sess., 26 (1945)." Citizens to Preserve Overton Park, Inc. v. Volpe, 401 U.S. 402, 410 (1971).

73. Cf. 38 U.S.C.A. $\$ 211$ (a) (West Supp. 1977):

[T]he decisions of the Administrator on any question of law or fact under any law administered by the Veterans' Administration providing benefits for veterans and their dependents or survivors shall be final and conclusive and no other official or any court of the United States shall have power or jurisdiction to review any such decision by an action in the nature of mandamus or otherwise.

74. During congressional hearings in 1970 and 1971 , several members of Congress who had helped to draft the LMRDA expressed concern that private rights sliould be given greater recognition in the Secretary's enforcement of Title IV. Senator Jennings Randolph, a member of the Conference Committee that drafted the final version of the LMRDA, stated that "the basic thrust of the Landrum-Griffin Act, as passed in 1959, was to give to the individual worker a more direct and wholesome participation in the procedures and policies within the union at the many levels to which he had the membership and the access." UMIV Hearings $I I$, supra note 8 , at 64. Senator Robcrt Griffin, one of the original House sponsors of the LMRDA, stated that "a primary 
Supreme Court ${ }^{i 5}$ of the complainant's interest in a Title IV suit, Congress should also amend Title IV to guarantee complainants notice of a decision not to bring suit, a right to be heard, and administrative review of adverse decisions. At a minimum, the Labor Department should promulgate rules requiring such procedures.

\section{A. Administrative Reforms}

The proposed reforms would alter current procedures by providing complainants notice and the right to be heard during the Department's investigation and the right to appeal adverse decisions to a professional review officer.ic These reforms, modeled largely on the procedures used to initiate NLRB unfair labor practice cases and representation cases, ${ }^{77}$ would revise the decisionmaking procedures of the Labor-Management Services Administration (LMSA), ${ }^{78}$ but the basic structure and investigatory nature of the LMSA's activities would not be changed.

The process now begins when the union member files a complaint with an LMSA Area Office. The Area Office first determines whether the complainant has exhausted his internal union remedies and has filed his objections with the LMSA in a timely fashion. If these requirements are met the Area Office undertakes an investigation-without consultation with the complainant-into the validity of the complainant's allegations and submits, usually within 30 days of receiving the

aim of Landrum-Griffin was to protect the rights of individual workers within a union." Id. at 46.

But I also believed that when courts came to a situation where doubt existed [as to

the meaning and purpose of Title IV of the Act], they would resolve the doubt in

favor of the objectives of the law, which are to protect the individual worker and

to give him the benefit of the doubt, as opposed to the entrenched union hierarchy.

But I must say, almost without exception, the Labor Department and the courts

have gone the other way, and consistently and persistently resolved all the doubts

in favor of the entrenched union hierarchy and against the individual worker.

Id. at 49. See also id. at 3-4, 48-50, 64 .

75. See Dunlop v. Bachowski, 421 U.S. 560 (1975); Trbovich v. UMW, 404 U.S. 598 (1972).

76. See Note, supra note 37 , at 500 (arguing for greater complainant input in Title IV decision process).

77. See generally NLRB FirLd Manual (rev. ed. 1971). See K. Divis, Discretion.iRY JUSTICE 207 (1969) (procedures of NLRB General Counsel's Office include "the major elements of a full structuring of discretionary power-findings, reasons, precedents, checks through appeals and through internal supervision, and procedural protections").

78. The LMSA is the division of the Labor Department that is responsible for administering most of the provisions of the LMRDA, including the provisions of Title IV. The LMSA is headed by the Assistant Secretary of Labor for Labor-Management Relations in Washington. The LMSA has six regional offices (New York City, Philadelphia, Atlanta, Chicago, Kansas City, and San Francisco) and 24 area offices. U.S. Dep'T

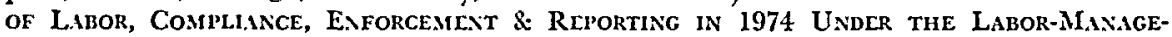
alent Reporting and Disclosure ACt 1, 114-15 [hereinafter cited as Complance 1974]. 
complaint, a Report of Investigation (ROI) to the Regional and National Offices. ${ }^{79}$ Based on the ROI, the decision (made in Washington) will be to bring suit if it appears that the violations the Area Office uncovered "may have affected the outcome of the election" 80 and that the case is "suitable for litigation." 81 The proposed reforms would alter this process by bringing the complainant's point of view into the investigation. ${ }^{82}$ Thus, the Area Director would appoint a hearing officer who would investigate the allegations of the complaint, consult with the union and complainant informally, collect sworn evidence in informal investigatory conferences or hearings, ${ }^{83}$ and seek

79. See Union Election CASES, supra note 67, at 4-5; Note, supra note 37, at 489-92.

80. See 29 C.F.R. $\$ 452.136$ (1976); UNION Election CASES, supra note 67, at 5.

81. The Labor Department considers a case "not suitable for litigation" if the evidence is of doubtful probity, the union reforms the challenged procedure, or the Department prefers to await the outcome of a similar case pending in court. See UNIoN ElECTION CASES, supra note 67, at 5. See also Note, supra note 37, at 498 (describing four situations which are, in practice, regarded as "not suitable for litigation").

82. Currently the local investigation does not seck the assistance and input of complainants. See Note, supra note 37 , at 500; note 103 infra.

83. There are two models which form the basis for the proposed investigatory procedures: the Labor Department's own procedures in formulating rules for rerun elections under Title IV and procedures other agencies use in conducting informal, non-adversarial hearings.

The proposed hearing resembles the Labor Department's "Pre-Election Conference" in which the Department recommends rules to be followed in elections supervised by the Secretary under Title IV. After notice, a public conference is held at which the complainant, officers, and other union members may discuss remedies and proffer additional conditions to govern the rerun election. A member who disagrees with the Secretary's final rules may contest the decision in court. See Brennan v. Sindicato Empleados Equipo Pesado, 90 L.R.R.M. 3087 (D.P.R. 1975) (describing pre-election conference and upholding the Secretary's rules).

NLRB representation procedures are similar to, although more formal than, the procedures proposed in this Note. See NLRB Field Manual, supra note 77, $\$ \$ 11000-11480$. After a petition is filed, the Area Office contacts all interested parties and conducts a preliminary investigation into the allegations. Id. $\$ \S 11000-11016$. Based on the results of this investigation the Regional Director determines whether a hearing is necessary. Id. $\$ 11080-11080.4$. An investigatory hearing is conducted at which the hearing officer entertains motions, seeks stipulations of fact and settlements, and arranges for an orderly development of pertinent evidence. $I d$. $\$ \$ 11180-11184,11200$. Evidence is not limited to that admissible in court and may include materials from the Area Office file, testimony of witnesses, stipulations, documents, and records. Id. \$§ 11216-11230. The final decision whether to hold an election is made by the Regional Director and may be reviewed by the NLRB. Id. $\$ \S 11274-11284$. This procedure-especially its delegation of decisionmaking -has recently been praised. Oversight Hearings on the National Labor Relations Board: Hearings Before the Subcomm. on Labor-Management Relations of the House Comm. on Education and Labor, 94th Cong., 1st Sess. 258, $281-82$ (1975) [hereinafter cited as NLRB Hearings]. For other examples of informal investigatory hearing procedures, see NATIONAL Labor Relations Board, Casehandling Manual (Part One): Unfair labor Practice Proceeding $\$ \S 10056-10056.8,10058-10060$ (1975) (description of NLRB Regional Office investigation to determine whether to prosecute unfair labor practice charge) [hereinafter cited as NLRB Casehandling ManUaL]; 38 C.F.R. $\$ 3.103$ (1975) (Veterans Administration hearing officer to assist claimant in seeking out all relevant information); 20 C.F.R. $\$ \$ 404.927-.934$ (1976) (Social Security Administration hearing officer questions witnesses, seeking out information on his own). 
formal determinations by which the union might remedy the violations voluntarily. ${ }^{84}$

Currently, all decisions to bring suit are made in Washington by the Solicitor of Labor and the Assistant Secretary of Labor for LaborManagement Relations, after consulting with the Deputy Solicitor and the Bureau of Elections and Trusteeships. ${ }^{85}$ The proposed reforms would leave such decisions to the Area Office. The Area Office would be required to give reasons for its decisions and those decisions would be final, unless the complainant or another union member appealed within ten days to a newly created Appellate Review Board, ${ }^{\mathbf{8 6}}$ consisting of three to eight Administrative Law Judges (ALJs). ${ }^{87}$ The Board would immediately assign the case to one of its members, who would decide the appeal within 20 days. If questions of law alone were at issue, the ALJ would render a decision in Washington, the standard of review being "clear mistake of law." If the appeal involved ques-

84. A "formal determination" is an agreement between the Department and the union that the latter will remedy the alleged violations voluntarily. UNion ErECrion Cases, supra note 67, at 5. Cf. NLRB Field MANUal, supra note 77, $\$ \S 11188,11200$. The Area Office should include in the agreement a provision that the 60-day limit on filing suit would be waived if the union violates the agreement.

85. See Union Election Cases, supra note 67, at 5; Note, supra note 37, at 496-99.

86. A direct analogue is the procedure for appeals to the NLRB General Counsel when a Regional Director refuses to file an unfair labor practices complaint. The Regional Director must provide a full statement of reasons for dismissing the charge. NLRB CaSEhanding Manual, supra note 83 , $\$ \S 10122-10122.8$. Interested parties may appeal the regional decision to the General Counsel in Washington, id. $\$ 10122.4$, and may appear in person to present evidence and argumentation. 29 C.F.R. $\$ 101.6$ (1976). The administrative decision after appeal is final and unreviewable in the courts. Vaca v. Sipes, 386 U.S. 171, 182 (1967) (dictum). Cf. 38 C.F.R. \$\$ 19.109-.112, 19.128-147 (1976) (appeal to Board of Veterans Appeals, with investigatory hearing at place convenient to claimant); 29 C.F.R. $\$ \$ 101.21(\mathrm{~d}), .23(\mathrm{~b})$ (1976) (appeal to NLRB in representation cases); 20 C.F.R. $\$ \S 404.945-.952$ (1976) (appeal to Social Security Appeals Council).

87. ALJs are professional decisionmakers who preside over agency hearings. They are appointed and certified by the Civil Service Commission (CSC) based on the Commission's examination of the applicant's personal and professional qualifications. See 5 C.F.R. $\$ 930.203$ (1976); Dullea, Development of the Personnel Program for Administrative Law Judges, 25 AD. L. REv. 41, 43, 45 (1973) (rigorous screening process to ferret out best qualified ALJs). An ALJ is assigned to an agency by the CSC. He is then governed and bound by the agency's rules and precedents but is still highly independent in that he cannot be transferred, promoted, assigned nonadjudicatory duties, or removed without the prior approval of the CSC. Id. at 46; Zwerdling, Reflections on the Role of an Administrative Law Judge, 25 AD. L. REv. 9, 12 (1973); 5 C.F.R. $\$ \S 930.204-.234$ (1976). See generally M. Ruhlen, Manual for Administrative LAw JudGes (1974). Based on length of service, judgment, and judicial expertise, the Commission grants pay raises and promotions, transfers ALJs from agency to agency (usually to agencies where they are at a higher civil service grade), and promotes ALJs to Chicf Judges. See 5 C.F.R. $\$ 930-204, .206$, .210 (1976); Miller, The Education and Development of Administrative Law Judges, 25 AD. L. REv, 1, 5 (1973). Because their careers depend on their objectivity and judgment, and because most ALJs appear to be well-qualified, appellate review systems using ALJs have been praised for producing more open, consistent, and accurate agency decisions. See notes 108 \& 109 infra. 
tions of fact, as is more likely, the ALJ would go to the Area Office to conduct an informal investigatory hearing to resolve factual disputes. ${ }^{88}$ The ALJ's opinion would be final ${ }^{s 9}$ and would determine whether the Labor Department brought suit.90 The objectives of the proposed reforms are to decentralize and professionalize the decisionmaking process and to give the complainant a greater opportunity to present his point of view. ${ }^{91}$

\section{B. Rulemaking}

In order to facilitate a fair hearing and meaningful review, the Labor Department should promulgate, through rulemaking subject to judicial review, ${ }^{92}$ guidelines for the decision process. $^{93}$ Under the

88. Cf. 38 C.F.R. $\$ 19.138$ (1975) (hearing for appellate review by Board of Veterans Appeals held in Washington or at locus near claimant's residence, at claimant's choice); 20 C.F.R. $\$ 404.949$ (1976) (when Social Security Appeals Council accepts new evidence, with $\mathrm{ALJ}$ or Council member appointed to receive evidence personally).

89. Cf. 38 U.S.C.A. $\$ 211$ (a) (West Supp. 1977) (decision of Board of Veterans Appeals final and unreviewable); 20 C.F.R. $\$ \$ 404.950-.951$ (1976) (decision of Social Security Appeals Council final).

90. During the ALJ's investigation, the hearing officer and the Area Office might continue negotiations with the union to seek settlement of the case or voluntary compliance and could be given limited powers to obtain from the union an extension of the time for filing suit. However, the Secretary should adopt rules and procedures to govern the decision to seek an extension. See Note, supra note 34, at $1225-27$ (suggesting that the Labor Department adopt express standards for seeking extensions and give complainants a chance to request expeditious handling of a case).

91. There are three ways to protect the complainants' interests in lieu of-or in addition to-the reforms suggested in this Note. Two alternatives-granting a more expansive scope of review and allowing complainants to bring their own suits against unions-do not adequately reflect Congress's concern that unions be protected from diffuse and potentially frivolous litigation. The third possibility is to allow complainants to bring pre-election suits under Title I of LMRDA, 29 U.S.C. $\$ \$ 411-413$ (1970), to protect individuals' rights to vote and to run for union office. These suits are less disruptive than the post-election suits brought by the Secretary, and it is arguable that Congress did not intend to foreclose these suits to complainants. See generally Note, Pre-Election Remedies Under the Landrum-Griffin Act: The "Twilight Zane" Between Election Rights Under Title IV and the Guarantees of Titles I and V, 74 Colum. L. Rev. 1105 (1974).

92. Under APA informal rulemaking procedures, 5 U.S.C. $\$ 553$ (1970), the agency must (1) publish notice of proposed rulemaking, including a description of the issucs involved, (2) give interested persons an opportunity to participate through submission of written documents, with or without opportunity for oral presentation, and (3) formulate final rules, incorporating therein "a concise general statement of their basis and purpose." See Pickus v. United States Bd. of Parole, 507 F.2d 1107 (D.C. Cir. 1974) (rules invalid, because of insufficient public notice); IVright, The Courts and the Rulemaking Process: The Limits of Judicial Review, 59 CORNeLL L. REv. 375, 380, 395-97 (1974).

Commentators have long urged the increased use of rulemaking. See, e.g., K. Davis, Administrative Law of the Seventies $\$ 6.13$ (1976); H. Friendly, The Federil Administrative Agencies (1962). Courts likewise have recognized the value of rulemaking in clarifying policy and protecting against arbitrary action. See, e.g., Silva v. Secretary of Labor, 518 F.2d 301, 311 (1st Cir. 1975).

93. At present, the Department of Labor has published no formal rules for decisionmaking. Existing rules interpreting $\$ 402$ do little more than summarize the 
revised Title IV, for instance, the Secretary would not bring suit if the proven violations were too insignificant to have affected the election's outcome or if the case were unsuitable for litigation. ${ }^{94}$ Rulemaking should be used to define standards for these cases. For example, more precise rules should be formulated for determining how much of an effect certain systemic violations of Title IV are presumed to have on the outcome of an election. ${ }^{95}$ The rules might take the form of generalizations or simple hypothetical cases; ${ }^{96}$ as such, they would offer uniform guidelines for hearing officers and ALJs, would give fair notice to complainants of the standards used to decide cases, and would be subject to judicial review to ensure that departmental policy comported with the goals of Title IV. ${ }^{97}$

A related purpose of rulemaking would be to give the Department flexibility to choose and to abandon areas of litigation in order to allocate prosecutorial resources efficiently and to effectuate the goals of national labor policy. ${ }^{98}$ Under the suggested reforms, the Labor De-

statutory provisions. Compare 29 C.F.R. $\$ \$ 452.135$-.136 (1976) (unilluminating rules interpreting LMRDA $\$ 402,29$ U.S.C. $\$ 482$ (1970)) with id. $\$ \$ 452.11-.134$ (1976) (detailed rules interpreting LMRDA $\$ 401,29$ U.S.C. $\$ 481$ (1970)). See also Note, supra note 37, at $516-17$ (criticizing the Department of Labor for not engaging in rulemaking).

Courts generally have not required agencies to formulate general rules for decisionmaking. See NLRB v. Bell Aerospace Co., 416 U.S. 267, 294-95 (1974). But cf. K. DAvis, DiscrerIon.arY JUStICE $68 \mathrm{n.17}$ (1969) (criticizing NLRB for failing to make rules for decisionmaking).

94. See p. 906 \& notes 80 \& 81 supra.

95. Cf. Steelworkers Local 3489 v. Usery, 45 U.S.L.W. 4089 (U.S. Jan. 11, 1977) (union rule that disqualifies $\mathbf{9 6 . 5 \%}$ of local employees from seeking office is presumptive violation of LMRDA \$ 401(e), 29 U.S.C. \$ 481(c) (1970)). The Court's decision may lead the Labor Department to formulate specific rules-in the form of hypotheticalsdefining further the import of the decision. Cf. 29 C.F.R. $\$ 452.38$ (a) (1976) (factors to consider in determining whether meeting-attendance eligibility requirements violate LMRDA).

96. See K. Davis, Discretonary Justice 60 (1969): "[A] rule need not be in the form of an abstract generalization; a rule can be limited to resolving one or more liypothetical cases, without generalizing." One such hypothetical is contained in a Labor Department booklet designed to help union members understand their rights under the LMRDA. See LMSA, Electing UNion OfFicers 22 (1974): "For example, if one member was improperly denied the right to vote but all election contests were won by more than one vote, the Secretary would not bring a civil action because the violation could not have affected the election outcome for any office."

97. Congress should limit judicial review to independent attacks on departmental rules outside the context of particular enforcement proceedings. $C f$. Yakus v. United States, 321 U.S. $414,427-31$ (1944) (Congress has the power to provide that administrative rules may not be collaterally attacked in enforcement proceedings).

98. Such flexibility is necessary for the continued evolution of national labor policy. See Complance 1974, supra note 78, at 5-8 (describing Secretary's suits challenging attendance requirements which preclude many union members from being nominated to union office); Steelworkers Local 3489 v. Usery, 45 U.S.L.W. 4089 (U.S. Jan. 11, 1977) (Supreme Court agrees with Secretary's interpretation that rule disqualifying $96.5 \%$ of members from seeking office violates Title IV'). 
partment could continue to fine-tune its enforcement program; this fine-tuning would be accomplished, however, by rulemaking rather than by ad hoc agency decisions. ${ }^{9}$ To demand that an agency engage in self-limitation by promulgating sules is to demand not that an agency surrender its flexibility, but that it eschew resort to unprincipled or inconsistent decisions. ${ }^{100}$

\section{The Proposed Reforms and Title IV}

The proposed administrative reforms mandate no fundamental changes in the Title IV decisionmaking process. Yet by restructuring administrative discretion the reforms would resolve Title IV's conflicting goals better than the Supreme Court was able to do in Bachowski. ${ }^{101}$ The reforms would enhance the perceived fairness of decisions and give complainants a meaningful chance to be heard, without contravening other important goals of Title IV.

\section{Fairness to Complainants and Protection of Their Statutory Rights}

Title IV complainants and members of Congress have criticized the Labor Department's present procedures as unfair. ${ }^{102}$ Critics have ob-

99. "Interpretive" rulemaking (where there is no provision for public comment and judicial review) is now used by the Department to present its policy interpretations of Title IV to unions. See 29 C.F.R. $\S 452.1$ (1976). See also U.S. DeP'T of Labor, Compliance, Enforcement \& Disclosure in 1973 Under The Labor-ManageMent Reporting ANd Disclosure Act 7 n.2 (Secretary responded to developing caselaw on the use of absentee ballots by promulgating a revised interpretive bulletin keyed to specific court cases). It would be little additional burden for the Department to issue formal rules, with opportunity for public comment. For example, the United States Parole Commission revises its policies (embodied in its "Guidelines for Decisionmaking" chart governing release on parole) through formal rulemaking with opportunity for public comment. See 28 C.F.R. $\$ 2.20$ (1976). The Commission is able to publish revisions several times a year to fine-tune its regulations to meet changing policy goals. See, e.g., 41 Fed. Reg. 52889 (1976) (notice of rulemaking promulgated November 26, 1976, with comments due by January 24, 1977, the final rule being issued at or near that date).

100. See K. Davis, Administrative Law Text $\$ 6.03$ (1972).

101. If Congress does not amend Title IV to preclude judicial review, the procedures and rulemaking discussed above would still be useful reforms. Besides providing effective notice and hearing for the complainant, the reforms would make judicial review a more effective check by building a record suitable for judicial examination. See, e.g., Silver v. New York Stock Exch., 373 U.S. 341, 362-63 (1963); National Rifle Ass'n v. United States Postal Serv., 407 F. Supp. 88, 91 (D.D.C. 1976). See note 49 supra.

102. For the strident (and often partisan) attacks of dissatisfied complainants, sec AutocracY, supra note 7, at 13-14, 17-18, 29, 55-56, 62, 117-20, 259; UMW Hearings $I I$, supra note 8 , at 5-6, 16, 24-25, 31-32, 61-63. For congressional criticisms, see id. at 1-3, 46-50, 63-64, 70-71. Senator Robert Griffin has been an especially acute critic of the Labor Department's enforcement of Title IV: “[I]t appears to me that the Labor Department is very reticent about protecting the rights and interests of the rank and file." Id. at 46. 
jected that the complainant has no opportunity to contribute either his evidence or his point of view, whereas union leaders are often in close contact with the Department's investigation. ${ }^{103}$ They also argue that the standards governing decisions are vague and often suspect. ${ }^{101}$ Thus the present decisionmaking structure promotes at least the $a p$ pearance of unfairness. ${ }^{105}$ Because judicial review under Bachowski disclaims any inquiry into the factual basis of the Secretary's decisions, it has done little to allay doubts as to their propriety. ${ }^{108}$

The proposed reforms would enhance both the appearance and reality of fairness in three ways. First, through public rulemaking procedures, the Secretary would formulate guidelines for decisionmaking that would constitute effective notice to complainants of what they must show in order to merit a Title IV suit. Second, the Secretary's investigation would be more open to participation by the com-

103. The most common objection is that the Labor Department's investigatory and decision process is biased toward incumbents, since the local office consults the union in the course of an investigation (e.g., seeking evidence and possible settlement), but often ignores the complainant entirely. For instance, in 1970 union dissidents complained about violations of the LMRDA in the elections of District 5, UMW. Although the dissidents were eager to assist in the investigation, the Labor Department gave them little if any notice of its progress and instead entered into negotiations with the union. UMW Hearings $I I$, supra note 8, at 31-34, 61-64. Kenneth Yablonski, an attorney for the complainants, objected that the Labor Department's nonenforcement was "a shocking example of poor administrative procedures, a built-in proincumbent bias ... and a disregard for the private rights of union members." Id. at 63. For other complaints that the departmental procedure has a pro-incumbent bias, see Brief for Petitioner at 13-14, 20 n.10, Trbovich v. UMW, 404 U.S. 528 (1972); Motion to Intervene at 6-7, Brennan v. Plumbers Local 449,64 F.R.D. 633 (IV.D. Pa. 1974) (alleging Department ignored complainant in handling Title IV suit); Applicants' Supplemental Memorandum in Support of Motion to Intervene as Plaintiffs, Brennan v. Connecticut State UAW Community Action Program Council, 60 F.R.D. 626 (D. Conn. 1973) (same); Hall, Law, Democracy and the Unions, in AutocracY, supra note 7, at 109, 119-20; Spira, Rebel Voices in the $N M U$, in id., at 47, 55-56; Note, supra note 37 , at 500-02.

104. Complainants often appear to resent the fact that all decisionmaking occurs in Washington, where a suit may be denied because it is deemed "not suitable for litigation." See Note, supra note 37, at 498. This resentment may stem from a strong (although unverified) suspicion that political influences improperly affect outcomes. See id. at 499-500 (counsel for complainants and unions share this suspicion); Hall, Labor Insurgency and the Legal Trap, in AuTOcRAcY, supra note 7, at 255, 259-64.

105. Most complainant resentment against the Department seems to be galvanized not by official wrongdoing, but by departmental procedures and policies. See, e.g., UMW Hearings $I I$, supra note 8 , at 91-95, 104-05, 123-28, 199-207 (correspondence between UMWW dissidents and Department).

106. Complainants obviously consider judicial review under Bachowshi unresponsive to their factual objections to the Secretary's refusals to sue. See, e.g., Plaintiff's Motion to Vacate Judgment, Fletcher v. Dunlop, 91 L.R.R.M. 2113 (N.D. Ill. 1975); Bachowski v. Brennan, 405 F. Supp. 1227, 1233-34 (W.D. Pa. 1975). At least one district court has criticized the Labor Department's failure to be responsive to the complainant's contentions in its reasons statement. See Valenta v. Brennan, 90 L.R.R.M. 3316 (N.D. Ohio 1975), appeal dismissed, No. 76-1122 (6th Cir. Feb. 24, 1977). 
plainant and other union members. ${ }^{107}$ Third, the process of investigation and review would be more professional, owing to the greater use of ALJs. ${ }^{108}$ By opening up and furnishing standards for the decision process, these reforms would provide a continuing check against administrative arbitrariness; ${ }^{109}$ and by providing for notice, participation in the investigatory process, opportunity to present and examine evidence, and professional administrative review by a disinterested

107. Courts and commentators long have recognized the importance of public participation in agency investigations and hearings. See National Welfare Rights Organization v. Finch, 429 F.2d 725, $737-38$ (D.C. Cir. 1970); K. Davis, AdMinistrative LAw Treatise $\$ 22.08$ (Supp. 1972); Cramton, The Why, Where and How of Broadened Public Participation in the Administrative Process, 60 GEo. L.J. 525, 527-30 (1972); Shapiro, Some Thoughts on Intervention Before Courts, Agencies, and Arbitrators, 81 HARv. L. REv. 721, 722-23 (1968). Congress likewise has stressed the need for increased participation in agency proceedings as a means of protecting private interests and of reaching decisions consistent with the broader public interest. See, e.g., Public Participation in Federal Agency Proceedings: Hearings on 5.2715 Before the Subcomm. on Administrative Practice and Procedure of the Senate Comm. on the Judiciary, 94th Cong., 2d Sess. 2 (1976) (statement of subcommittee chairman Edward Kennedy).

108. Recent congressional hearings have emphasized the need for increased delegation of agency decisionmaking to professional hearing officers and ALJs. See Oversight of CAB Practices and Procedures: Hearings Before the Subcomm. on Administra. tive Practice and Procedure of the Senate Comm. on the Judiciary, 94th Cong., Ist Sess. 442, 1154-61 (1975); Administrative Procedure Act: Hearings on S.51S Before the Subcomm. on Administrative Practice and Procedure of the Senate Comm. on the Judiciary, 90th Cong., Ist Sess. 249-55 (1967) (article by Frank Cooper) [hereinafter cited as $A P A$ Hearings]; id. at 295 (statement of Merritt Ruhlen, Federal Trial Examiners Conference).

Decisionmaking models embodying an initial determination by a hearing officer followed by administrative review by an appeals board or ALJ have been praised for producing decisions that are well respected and cogently reasoned. See Gillilland, The Certiorari-Type Review, 26 AD. L. REv. 53 (1974) (examining and commending appellate review boards in FCC, ICC, CAB, Patent Office, AEC, SEC); cf. Berkemeyer, Agency Review by Intermediate Boards, 26 AD. L. REv. 61, 64-66 (1974) (citing advantages of FCC's delegation of review power to professional hearing officers: accuracy, better quality of opinions, increased predictability and consistency, separation of policy making and adjudicatory functions). See generally 1 Recommexditions AND Reports of the Administrative Conference of the United States 122 (1968-1970) (Committee Report on Recommendation 6, "Delegation of Final Decisional Authority Subject to Discretionary Review by the Agency"); Note, Intermediate Appellate Review Boards for Administrative Agencies, 81 HARv. L. REv. 1325 (1968) (examining FCC, ICC, CAB review boards and recommending that agencies rely more extensively on such professional decisionmakers).

109. See note 113 infra. An instructive parallel may be found in the West German judicial system. That system provides for administrative review of prosecutorial decisions in criminal cases. If the prosecutor decides not to bring suit against an accused person, a private citizen may file a departmental complaint, initiating review of the decision by an official in the prosecutor's office; in addition, each prosecutor is supervised by a superior, who periodically reviews the prosecutor's files. Commentators have praised the procedures as an impartial and effective check on prosecutorial discretion, because the review is conducted by a professional at a higher level in the bureaucratic hierarchy. See Herrmann, The Rule of Compulsory Prosecution and the Scope of Prosecutorial Discretion in Germany, 41 U. CHI. L. REv. 468, 503-04 (1974); Langbein, Controlling Prosecutorial Discretion in Germany, 41 U. CHr. L. REv. 439, 465-66 (1974). See generally K. Davis, Discretronaky Justice 194-95 (1969). 
decisionmaker, the reforms would contribute to greater public and complainant satisfaction with the fairness of Labor Department decisions. ${ }^{110}$

Thus, precluding complainants from seeking judicial review of the Department's decisions would be neither an unconstitutional denial of due process ${ }^{111}$ nor an elimination of a functionally independent check against abuse of discretion in the Labor Department. ${ }^{112}$ The largely ineffectual judicial check against arbitrary agency action would be replaced with an open system of publicly promulgated standards, complainant input, and factual review of initial decisions. It has been persuasively argued that the latter system is often a more effective check on administrative arbitrariness-especially in the area of prosecutorial discretion-than is judicial review for "abuse of discretion."113

Besides ensuring procedural fairness and enhancing the perceived legitimacy of the Secretary's decisions, the proposed reforms would pro-

110. See LaTour, Houlden, Walker \& Thibaut, Procedure: Transnational Perspectives and Preferences, 86 YALE L.J. 258, 283-84 (1976).

111. See Ortwein v. Schwab, 410 U.S. 656, 660 (1973) (per curiam) (administrative procedures provide adequate due process; no due process right to judicial review). Cf. Saez v. Goslec, 463 F.2d 214 (lst Cir. 1971) (per curiam), cert. denied, 409 U.S. 1024 (1972) (charging party's legal interest in NLRB unfair labor practice complaint is not sufficiently serious to merit due process protection). On the other hand, due process may require that courts adjudicate constitutional challenges to statutes and rules. Johnson v. Robison, 415 U.S. 361, 366-73 (1974) (Congress's foreclosure of review of Veterans Administration decisions docs not preclude constitutional challenges to Veterans Readjustment Act of 1966); Oestereich v. Selective Service Bd., 393 U.S. 233, 241-44 (1968) (Harlan, J., concurring) (constitutional challenge to Selective Service's published regulations not precluded by Congress). But see note 97 supra.

112. In general, agency appellate review boards have been respected for their impartiality. See note 108 supra. Moreover, the careers of ALJs depend on their professional objectivity and independence of judgment, see note 87 supra; hence, it is not surprising that other agencies using ALJ decisionmakers have found the procedures helpful and sympathetic to claimants. See, e.g., Popkin, Effectiveness of the Social Security Rcview System in Disability Cases, 26 Ab. L. Rev. 79, $82-83$ (1974); Smith, Social Security Appeals in Disability Cases, 28 AD. L. Rev. 13, 25 (1976).

113. K. Davis, Discretionary Justice 205.07, 226-28 (1969), argues that openness is the best check on administrative arbitrariness and sets up as a model of open decisionmaking the NLRB's handling of unfair labor practice cases. The administrative reforms proposed in this Note are modeled in part on the procedures used in unfair labor practice cases. Sce p. 905 supra. Indeed, most of the recent literature favoring limitations on prosecutorial discretion de-emphasize judicial review and endorse openness and administrative structuring of discretion as the most effective checks on abuse. See Bubany \&. Skillern, Taming the Dragon: An Administrative Law for Prosecutorial Decision Making, 13 Am. CRIM. L. REv. 473, 495-503 (1976) (proposing published rules and policies, administrative safeguards, and limited judicial review as best means of controlling prosecutorial discretion); Cox, supra note 62, at 395, 399-403, 434 (advocating administrative openness as the "soundest solution to the problems of prosecutorial discretion" and warning against dangers of "judicialization" of prosecutor's decisionmaking); $c f$. K. Davis, Administrative LaW of the Seventies $\$ 28.00-1$ (1976) (favoring administrative standards, findings, reasons, systems of precedents as best checks on prosecutorial discretion). See note 109 supra. 
vide greater protection for the complainant's rights. The recommended procedures would be superior to judicial review under Bachowski because they would afford the complainant easier access to the review process, would enable him to be heard at a more meaningful time, and would no longer burden him with a heavy judicial presumption against his position.

The agency review process would be more accessible because it would bring the complainant's viewpoint directly into the investigatory process, at small expense and minimal red tape for the complainant. The Area Office would be required to consider the complainant's testimony and other evidence during the investigation and to assist him in framing his objections if he disagrees with the hearing officer's decision. ${ }^{114}$ On review, the ALJ would elicit pertinent information from the complainant and other union members. ${ }^{115}$ As a result, the complainant need not hire an attorney. ${ }^{116}$ Should he choose to hire an attorney the cost would not be great, in view of the informality of the procedures and the short time devoted to decision and appeal. Presently, few complainants can afford the expense of judicial review; by replacing judicial review with more informal, less time-consuming procedures, the proposed reforms would make it easier for the average union member to obtain a hearing. ${ }^{117}$

The new procedures also would permit the complainant to obtain a hearing early in the decision process, when a hearing is more meaningful. The Bachowski Court characterized the Secretary as the complainant's "lawyer" and the reasons statement as part of his duty

114. Cf. 38 C.F.R. $\$ 3.103$ (1975) (Veterans Administration hearing officer assists claimant in seeking out all relevant evidence); U.S. DEP'T of HEALTH, EdLC., AND WELFARE, Social Security Handbook $\$ \S 118-124,2009$ (5th ed. 1974) (government personnel provided to assist claimants).

115. Cf. Smith, stepra note 112, at 25 (ALJs in Social Security hearings usually helpful to claimants in development of their cases).

116. The assistance of an attorney, while not necessary, will probably be helpful, especially in appealing adverse decisions. Cf. Aoministrator of Veterans Affairs, ANNUAl Report 1975, at 115. But cf. Popkin, supra note 112, at $84-85$ (Social Sccurity claimants benefit from using paralegals).

117. See K. Davis, Discretionary Justice 145 (1969):

By and large, administrative appeals are in many aspects preferable to judicial review, especially for small cases, because they are less expensive, because in many of them a party need not be represented by counsel, and because they usually reach the merits of cases without becoming enmeshed in legal technicalities that plague reviewing courts ....

Of course, if complainants could be awarded attorneys' fees the cost of judicial review would be less of an obstacle. See Usery v. Local 639, Teamsters, 543 F.2d 369 (D.C. Cir. 1976) (dictum) (proposing that courts award attorneys' fees to Bachowski plaintiffs if "common benefit" accrues to union members). 
towards his client. ${ }^{118}$ The Secretary would discharge his duty better by also engaging his client in prior consultation. Under the proposed reforms the complainant's opinions, factual data, and rebuttal evidence would be part of the record upon which the decision to sue is made and reviewed. ${ }^{119}$ In this way, the complainant's factual presentation would become an important part of the decision process and could not be ignored, as it is under the narrow scope of review Bachowski prescribes.

Finally, the new procedures would relieve the complainant of the heavy presumption of agency correctness that inheres in judicial review for abuse of discretion under an "arbitrary and capricious" standard. Instead, the ALJ would reverse the hearing examiner and direct that suit be brought in cases where the examiner had committed material errors of fact or law. ${ }^{120}$

\section{Minimum Interference in Union Affairs}

Not only would the proposed reforms afford greater protection for the complainant's interest than judicial review, but they would do so with far less risk of impairing other statutory goals. Congress vested the Secretary with exclusive power to bring Title IV suits in order to shield unions from frivolous litigation and to effect speedy resolution

118, 421 U.S. at 572. Cf. Trbovich v. UMW, 404 U.S. 528, 538-39 (1972): “[T]he statute gives the individual union members certain rights against their union, and 'the Secretary of Labor in effect becomes the union member's lawyer' for purposes of enforcing those rights. 104 Cong. Rec. 10947 (remarks of Sen. Kennedy)."

119. Complainants are often willing and even anxious to contribute pertinent information to facilitate the departmental investigation. See, e.g., UMIV Hearings II, supra note 8 , at 79, 222-25 (documents suggesting evidentiary leads and interpreting union constitution); id. at 106-11, 134-45, 166-71, 185-91, 229-71 (letters from complainants' counsel, with factual information and legal argument); id. at 150-61 (affidavits, including several pro se, handwritten affidavits). By permitting complainants to intervene in Title IV suits, the Court in Trbovich v. UMW, 404 U.S. 528, 537 n.8 (1972), implicitly recognized the value of complainants' special knowledge of unions' internal structures and of the subtle devices that may be used to influence election results. See Brief for Petitioner at 42-43, Trbovich v. UMW, 404 U.S. 528 (1972). Subsequent case law under Trbovich has confirmed the value of complainants' participation. See Usery v. Local 639, Teamsters, 543 F.2d 369, 384-85 (D.C. Cir. 1976) (remanding to determine whether intervenors were entitled to attorneys' fees on account of their expertise in unearthing "material and even elusive evidence" and in developing "telling arguments in support of the Secretary's claims of illegality"); Bibbs v. Brennan, No. 74-1562 (C.D. Cal. Aug. 1, 1974) (Secretary's error in interpreting union constitution corrected by complainant).

120. This standard is far more liberal than the "arbitrary and capricious" standard of review under Bachowski. Compare Dunlop v. Bachowski, 421 U.S. 560, 572-75 (1975) with 20 C.F.R. $\$ \$ 401.917-.940,401.945-950$ (1976) (Social Sccurity Appeals Council engages in de novo factual review). Of course, no "separation of powers" questions arise when an ALJ within the Labor Department reverses the decision of the hearing officer and "compels" suit. Cf. Nader v. Saxbe, 497 F.2d 676, 679 nn.18 \& 19 (D.C. Cir. 1974) (noting federal courts have generally refused to mandate prosecution of particular individuals at request of private persons). 
of post-election disputes. Judicial review has frustrated these goals by enmeshing unions in protracted litigation. The proposed reforms would resolve complainant objections more swiftly and with less intrusion into union affairs.

Under the proposed reforms the Secretary's screening function is restored. Unions are spared the expenses of litigation unless expert decisionmakers within the Labor Department find probable cause to believe the complaint is meritorious. The union, of course, is free to participate in the administrative process and may elect to do so. But its presence cannot be coerced, as it is by joinder in suits for judicial review. Moreover, since the administrative procedures would remain essentially investigatory, rather than adjudicative, the union would not be burdened with formal pleadings, motions for discovery, large attorneys' fees and court expenses, or the publicity and harassment that frequently accompany a lawsuit. ${ }^{121}$

The proposed reforms would likewise preserve the statutory goal of speedy resolution of post-election disputes. The existing timetable for investigation would be retained, and most complaints would be processed to a conclusion within the 60-day limitation period. ${ }^{22}$ The new procedures depart from the present system mainly by providing a hearing at the investigatory stage of the process and internal review after the initial decision regarding suit is made. The addition of an investigatory hearing should not occasion delay: indeed, the similar (though more judicialized) hearing procedure used in NLRB representation cases has proved expeditious. ${ }^{123}$

121. Union officers currently have a legal duty to cooperate with the departmental investigation by providing the Area Office with documents and information. See, e.g., Brennan v. Independent Lift Truck Builders Union, 490 F.2d 213, 216 (7th Cir. 1974) (union duty to supply documents relevant to Secretary's investigation). The proposed procedures should prove no more burdensome. The hearing officer and ALJ would control the hearings, much as the Area Office now coordinates the investigation; complainants would have no independent discovery rights against the union or its officers. Attorneys should not be necessary, since the presiding officer would minimize legal technicalities by concentrating on the facts of the case and the applicable rules. Such "non-judicialized" procedures have found favor elsewhere. The NLRB (in representation cases) and Social Security Administration (in disability cases) have defended their informal processes and opposed "judicializing" decisionmaking hearings with formal pleadings, discovery, and rules of evidence. APA Hearings, supra note 108, at 219, 226-28 (statement of Frank W. McCulloch, then Chairman of NLRB, stressing the need for informal, rather than judicial and adversarial, procedures in NLRB representation hearings); id. at 151-52 (statement of Wilbur Cohen, then Under Secretary of HEW, praising nonadversarial Social Security hearings).

122. Exceptions may occur, as under the present system, for negotiating consent agreements. That is, the union may waive the 60-day limitation period in hopes of settling the case out of court. See note 34 supra.

123. The NLRB conducted 9112 representation elections in fiscal 1974. Eighty-two per cent of these elections were conducted within 44 days of the filing of the original 
The internal review process, moreover, will in large part replicate current LMSA procedures. At present, the decision to sue is made in Washington, based on review of the file and recommendations of the Area and Regional Directors. ${ }^{124}$ Under the proposed reforms, the decision to sue would be made by an ALJ, based on review of the opinion and record of the hearing examiner. Because the internal review process would be nonjudicial it should move swiftly. Experience in the NLRB General Counsel's Office and the Veterans Administration, for example, suggests the value of such informal procedures in eliminating formalized motions and minimizing delay. ${ }^{125}$ It is a fair estimate that between 20 and 60 decisions would be appealed to the newly-created Review Board each year. ${ }^{126}$ The three to eight ALJs on the Board should be able to handle this caseload expeditiously. ${ }^{127}$ Finally, few of the appealed cases should require an entire de novo proceeding. Most will involve questions of policy interpretation or discrete facts; the ALJ would limit his review to the issues raised on

petition. This 44-day period included the time spent on investigation, hearings, and preparation of a final decision by the Regional Director. See NLRB Hearings, supra note 83, at 6-7. This record is especially impressive, since NLRB representation cases, unlike Title IV cases, are adjudicated under no statutory time pressures.

124. See p. 907 supra.

125. In the late 1960s, the General Counsel decided appeals in an average of just over 20 days. See Office of the General Counsel, National Labor Relations Board, SUMMARY OF OpLRATIONs 1969-70, at 29. For a description of the procedures for General Counsel appeals, see note 86 supra. In fiscal 1974, disposition of cases certified to the Board of Veterans Appeals took on average about two months. Almost 1000 cases were processed by formal hearing before the Board. Administrator of Veterans AFFAIRS, ANNUAL RePORT 1974, at 121. The Review Board proposed for Title IV cases would be required to process far fewer cases, see note 126 infra, and would be held to rigid time limits.

126. During fiscal 1965.1974, an average of 130 Title IV complaints were filed with the Labor Department annually. About 45 complaints were dismissed each year in the Area and Regional Offices because the complainant either failed to exhaust union remedies or failed to file his complaint in a timely manner, or because the Area Office found no violations. In about 24 cases each year the Labor Department secured "voluntary compliance," where the union took corrective action without the need for bringing suit. Complinice 1974, supra note 78 , at 4 . Under the proposed administrative procedures, only a few of these cases (mostly those in which the Area Office found no violations) would be appealed beyond the Area Office. Of the remaining 60 cases (those in which suit was brought or where violations were found not to have affected the election's outcome), it is a fair guess that $25 \%$ to $50 \%$ would be appealed. Cf. 41 NLRB ANN. Rer. 210 (1976) (Table 3B) (of 2282 NLRB representation cases decided by Regional Directors in fiscal year 1975, requests for review were filed in 652 cases). This would suggest that the newly-created Review Board would have to handle between 15 and 30 cases annually. More recent statistics (fiscal year 1974) would suggest the somewhat higher range of 20-45 cases annually. CoMsLIANce 1974, supra note 78, at 4 .

127. If each $\mathrm{ALJ}$ handled only one case per month, four $\mathrm{ALJ}$ s would be sufficient to handle a caseload projected from 1974 statistics. 
appeal and supported by specific rebuttal of the hearing examiner's decision. ${ }^{128}$

\section{Conclusion}

Dunlop v. Bachowski is an important example of the functional, if not theoretical, limits of judicial review. In extending review to Title IV decisionmaking, the Bachowski Court overlooked two important facts: judicial review itself may undermine the scheme of statutory enforcement chosen by Congress, and a scope of review that is too narrow may strip judicial scrutiny of its legitimizing and checking functions. Judicial review is no panacea; the Bachowski line of cases illustrates one area of law where judicial review is not desirable.

Yet Bachowski does call attention to an important private interestthe union member's interest in the Secretary's Title IV suit-that had previously been slighted by courts and the Labor Department. The Court has initiated a court-agency dialogue that is groping torvards standards and, one would hope, procedures to protect the individual's interest. But the most the Court can do is to pose the problem. The ultimate solution must come from the Labor Department or Congress.

128. Cf. NLRB Field Manual, supra note 77, $\$ \S$ 10430-10438.4 (provision for exceptions to trial examiner's opinion to be filed by any party involved in representation case "to enable the Board to determine specifically what issues of substance or procedure it is being asked to decide"). 